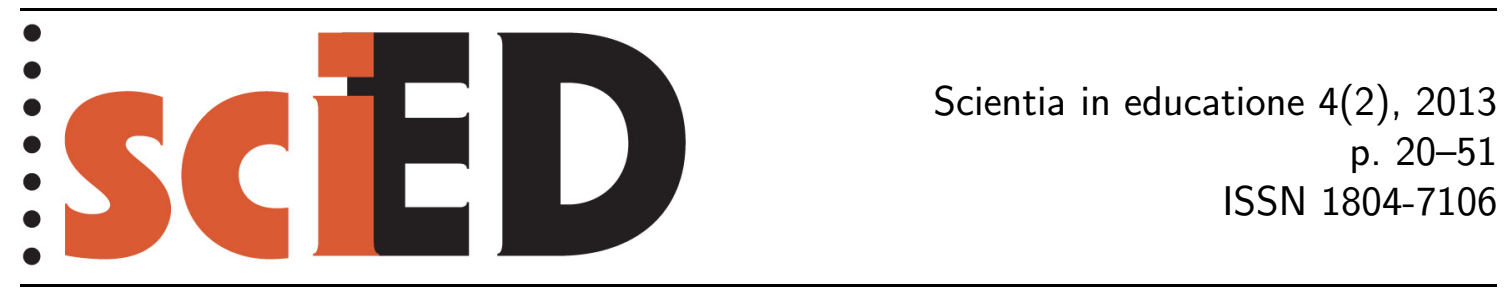

\title{
Analýza a priori jako součást přípravy učitele na výuku
}

\author{
Hana Nováková
}

\begin{abstract}
Abstrakt
Článek se zabývá výzkumem v rámci didaktického inženýrství tak, jak je zavedeno a rozpracováno $\mathrm{v}$ teorii didaktických situací. Zaměřuje se na analýzu a priori didaktických situací a na její vztah $\mathrm{k}$ př́pravám na výuku matematiky $\mathrm{v}$ praxi učitelů matematiky 1 . a 2. stupně a budoucích učitelů matematiky. $\mathrm{V}$ textu je podrobně popsán a analyzován experiment umožňující odhalit a vysvětlit možné př́činy rozdílů jednak mezi analýzou a priori podle teorie didaktických situací a př́ípravami učitelů, a také mezi jednotlivými skupinami učitelů.
\end{abstract}

Klíčová slova: analýza a priori, př́íprava učitele na výuku, teorie didaktických situací.

\section{A priori analysis as a part of teachers' lesson planning}

\begin{abstract}
The paper focuses on a research in the domain of didactical engineering as defined and described in the Theory of Didactical Situations. The research enquires into a priori analysis of didactical situations and its relationship to the process of lesson planning by primary and secondary in-service and pre-service mathematics teachers. The paper describes an experiment designed and carried out with the aim of pinpointing and giving account of the possible causes of differences between a priori analysis and teachers' lesson plans. It also shows and explains differences between primary, secondary and pre-service mathematics teachers.
\end{abstract}

Key words: a priori analysis, lesson plan, theory of didactical situations. 


\section{1 ÚVOD}

Učitel matematiky by měl ovládat nejen řešení matematických úloh, jejich výběr a didaktickou analýzu, ale měl by je také ve výuce uvést tak, aby dobře stimulovaly myšlenkové procesy žáků. Každou vybranou aktivitu by tedy měl dobře promyslet a naplánovat. V teorii didaktických situací v matematice je analýza a priori popsána jako profesní nástroj, který může učitelům při plánování výuky pomoci. Článek si klade za cíl analyzovat rozdíly mezi tím, co je zařazeno do analýzy a priori v teorii didaktických situací v matematice a skutečností v praxi učitele, vzájemně porovnat př́pravy zkušených učitelů a studentů učitelství a ukázat význam a využití analýzy a priori v učitelské praxi.

\section{ANALÝZA A PRIORI A Př́́PRAVA UČITELE NA VÝUKU}

\subsection{ANALÝZA A PRIORI A TEORIE DIDAKTICKÝCH SITUACÍ V MATEMATICE}

Podle Brousseaua $(1997,1998)$ a teorie didaktických situací v matematice (TDSM) ${ }^{1}$ je analýza a priori jedním $\mathrm{z}$ nástrojů, které má učitel při tvorbě přípravy $\mathrm{k}$ dispozici. Jejím cílem je co nejpodrobněji odhadnout průběh př́islušné výukové jednotky zejména se zaměřením na:

- rozdělení výukové jednotky do jednotlivých fází,

- možné reakce a postoje žáki̊ a reakce učitele na ně (překážky, chyby, jejich př́ípadné nápravy a opravy),

- možné strategie řešení úloh (správné i chybné),

- vědomosti a poznatky nezbytné pro jednotlivé strategie řešení.

Analýza a priori má tedy pro učitele velkou informační hodnotu: kromě toho, že mu umožňuje rozmyslet si obsah výuky a způsob, jakým bude onen obsah zprostředkovávat, poukazuje také na případná úskalí hodiny a možné obtíže žáků při řešení úloh.

Pro vysvětlení role analýzy a priori si nejprve připomeneme a objasníme některé základní principy TDSM. Následující odstavce jsou zpracovány na základě těchto zdrojů: Brousseau (2012), Brousseau (1998), Brousseau (1997), Brousseau (1984), Brousseau; Sarrazy (2002), Hrabáková (2005), Nováková (2013), Novotná (2003a, 2003b), Spagnolo, Čižmár (2003).

TDSM vychází z předpokladu, že ke každému matematickému poznatku je možné vymodelovat vždy alespoň jednu odpovídající matematickou situaci. Studuje tedy prvky (logické, matematické, ergonomické), které jsou potřebné pro vytváření takových situací.

\footnotetext{
${ }^{1}$ Autorem teorie didaktických situací v matematice (TDSM) je Guy Brousseau, emeritní profesor na IUFM d'Aquitaine a na francouzské Université Bordeaux II, nositel medaile Felixe Kleina. Na své teorii pracoval již od sedmdesátých let 20. století. V ucelené podobě ji poprvé představil v roce 1986. Postupně se setkala s př́znivým ohlasem i za hranicemi Francie. Zpočátku jejímu rozšiřování bránil fakt, že většina prací byla psána pouze ve francouzštině. Tato situace se ale v současné době mění a teorie se šiří do dalších evropských zemí (např. Velká Británie, Slovensko, Ceská republika), s velkým zájmem se setkala také ve francouzské části Kanady a dalších frankofonních zemích.
} 


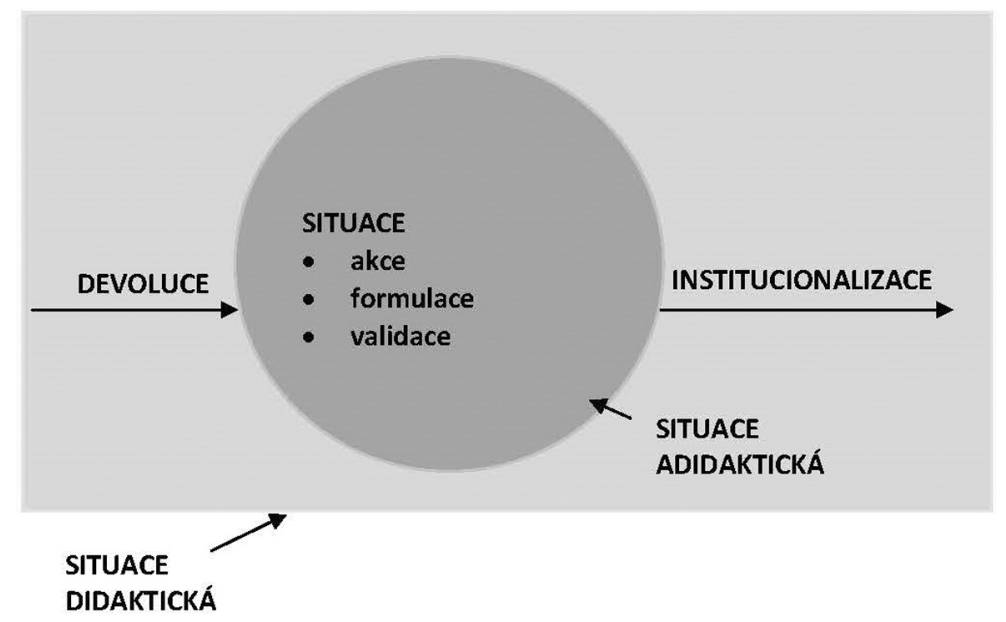

Obr. 1: Schéma didaktické situace podle Teorie didaktických situací

\subsubsection{PoznateK (CONNAissance) NEBO VĚdomost (SAVOIR)?}

V jazyce TDSM mají pojmy poznatek a vědomost odlišný význam. Poznatek je prostř̌edkem pro rozhodování, výběr činností, formulace důkazu apod. Slouží jako nástroj $\mathrm{k}$ dosáhnutí vědomosti. Umožňuje volit a měnit strategie řešení problému. Vědomosti jsou kulturní a sociální nástroje (prostředky) sloužící k identifikaci, ověření a použití poznatku. Jsou to vlastně institucionalizované poznatky.

V situacích, kde pracujeme s vědomostmi, používá žák poznatky jako prostředek, nikoli jako cíl. Jedna formulace může být poznatkem i vědomostí podle funkce, kterou v dané situaci plní. ${ }^{2}$

\subsubsection{TYPY MATEMATICKÝCH SITUACÍ}

Matematická situace je soubor okolností a vztahů, ve kterých se žák nachází. Vztahy situaci spojují s jejím prostředím. Situace je tedy systém, do něhož vstupuje učitel, žák, prostředí, pravidla a omezení potřebná pro vytvoření daného matematického poznatku.

Rozlišujeme dva typy matematických situací, situaci nedidaktickou a didaktickou.

Nedidaktickou situací rozumíme takovou situaci, ve které není žádný záměr vyučovat. Jde např́iklad o situace z běžného života, kdy se žádné učení neočekává (ale může k němu neplánovaně dojít).

Posláním didaktické situace je „někoho něco naučit“. Učitel organizuje plán činností, jejichž cílem je modifikovat nebo vytvořit žákovu znalost ${ }^{3}$.

Každá didaktická situace by měla podle TDSM obsahovat alespoň jednu adidaktickou situaci. Jejím cílem je umožnit žákovi získávat poznatky samostatně (devoluce). Tyto poznatky jsou následně shrnuty a rozvíjeny učitelem a stávají se z nich vědomosti (institucionalizace).

Adidaktická situace se skládá ze tř́i etap ${ }^{4}$ (viz obr. 1):

- Akce - výsledkem je předpokládaný (implicitní) model, strategie, počáteční taktika.

\footnotetext{
${ }^{2}$ Př́iklad: Vědomosti, které žáci získali při řešení kvadratických rovnic, slouží jako poznatek při zjištování průběhu polynomických funkcí (průsečíky s osami) a zároveň slouží jako poznatek při řešení rovnic s parametrem.

${ }^{3}$ Pojem znalost budeme používat v případě, že není důvod rozlišovat poznatek a vědomost.

${ }^{4}$ Výpočet se může objevit v kterékoliv etapě.
} 
- Formulace - zformulování počáteční strategie a podmínek, ve kterých bude tato strategie fungovat.

- Ověření (validace) - ověřní platnosti strategie - funguje, nefunguje, získaných výsledků.

Tyto situace mohou být různě řazeny za sebou tak, aby vytvořily proces učení se matematickému poznatku. Např. model formulace - ověření - akce je typický pro klasické hodiny matematiky, kdy situace ověření spočívá např. v provedení důkazu provedeného tvrzení nebo $\mathrm{v}$ jeho ověření v nějakém vzorovém př́kladu; situace akce pak znamená, že se aplikují vědomosti získané během situace formulace. Tato posloupnost vlastně odpovídá pojetí definice - věta - důkaz - procvičení. Každý matematický poznatek vyžaduje svi̊j vlastní proces učení se.

\subsubsection{PROMĚNNÉ V DIDAKTICKÉ SITUACI}

Didaktická situace je řízena proměnnými. Jde o soubor podmínek a omezení, které ovlivňuje sám učitel. Změnou proměnných měníme celou situaci. Kognitivní proměnná ${ }^{5}$ je proměnná, pro kterou existují alespoň dvě různé hodnoty, pro něž jsou optimální řešitelské strategie různé. Kognitivní proměnnou nazveme didaktickou, jestliže její hodnotu může stanovit vyučující. Formulační proměnná se týká formulace zadání úlohy.

\subsection{4 ÚKOLY UČITELE}

Učitel má v průběhu vyučovacího procesu dva hlavní úkoly. Prvním z nich je uskutečnit proces devoluce (viz obr. 1). Učitel předá část svých pravomocí, jež se týkají vyučování, žákovi. Pro žáka to naopak znamená přijetí části zodpovědnosti za vyučovací proces. V průběhu adidaktické situace učitel explicitně nezasahuje do práce žáků, žáci si řídí řešitelský proces sami. Devoluce je předpokladem adidaktické situace.

Druhým úkolem učitele je institucionalizace vědomostí (viz obr. 1). Tím rozumíme proces, kdy učitel shromáždí poznatky zjištěné žáky a převede je ve vědomosti. Institucionalizace následuje po ukončení adidaktické situace.

Podmínkou pro úspěšnou devoluci a následně pro vznik adidaktické situace je právě provedení analýzy a priori.

Charnay (2003) se zabývá analýzou a posteriori ${ }^{6}$, tj. analýzou, která se provádí po odučení konkrétní hodiny. Srovnávají se předpoklady vyslovené analýzou a priori se skutečným průběhem hodiny. Jejich srovnání umožní napřr. interpretovat neočekávané strategie a argumenty žáků, odhalit chyby, kterých se dopustili apod.

${ }^{5}$ Př́iklad: Narýsujte čtverec o délce strany $4 \mathrm{~cm}$.

a) Smíte použít jen pravítko a kružítko.

b) Máte k dispozici jen trojúhelník s ryskou a pravítko.

V zadání úlohy se vyskytují následující proměnné:

[Narýsujte] - formulační proměnná.

[délka strany] - kognitivní didaktická proměnná: učitel může zadat délku úhlopřričky čtverce, jeho obvod nebo obsah. Řešení úlohy pak budou odlišná.

[čtverec] - kognitivní didaktická proměnná: učitel může zadat jiný geometrický útvar a změní se tak konstrukce.

[4 cm] - didaktická proměnná, kterou nepovažujeme za kognitivní. Domníváme se totiž, že změna její hodnoty neovlivní významně strategii řešení.

[jen pravítko a kružítko]; [jen trojúhelník s ryskou a pravítko] - kognitivní didaktické proměnné, změna rýsovacích pomůcek podstatně ovlivní řešitelskou strategii.

${ }^{6}$ Jiní autoři používají termín reflexe. 


\subsection{PřÍPRAVA UČITELE NA VYUČOVACÍ HODINU}

Podle Harmera (1992) je klíčovou otázkou, kterou by si měl učitel při tvorbě přípravy položit, tato:

Co budou moji žáci pocitovat, vědět, nebo co dokáži udělat na konci hodiny (hodin) oproti tomu, co nepocítili nebo nevěděli nebo nedokázali udělat na začátku hodiny (hodin)? (Harmer, 1992) ${ }^{7}$

Zodpovězením těchto otázek učitel stanoví cíl hodiny. Harmer, podobně jako Obst (2002), zdůrazňuje, že cíl hodiny by neměl znát pouze učitel, ale měli by s ním být seznámeni i žáci, byt implicitně.

Řada autorů se také zabývá otázkou, jak by měla vypadat dobrá příprava. Většinou se shodují v tom, že při př́ípravě nestačí naplánovat, co budeme učit, ale je nutné rozmyslet, jakým způsobem hodinu zorganizujeme.

Podle Harmera (1992) existují dva hlavní principy dobré př́ípravy: rozmanitost a flexibilita. Rozmanitost spočívá v široké paletě nejrůznějších aktivit a materiálů tak, aby hodiny byly zajímavé a aby vznikla rovnováha mezi naplánovanými aktivitami, která je pro danou třídu nejvhodnější. Flexibilita se týká především učitele. Jde o schopnost přizpůsobit svůj plán měnící se situaci.

\subsubsection{PŘíSTUPY K PŘÍPRAVĚ}

Příprava na výuku je plně záležitostí učitele. Ten si postupně utváří vlastní pojetí pedagogické práce a tím i pojetí přípravy na ni.

Divíšek (1989) uvádí dva často se objevující přístupy k přípravě, které se vyskytují hlavně u začínajících učiteli̊. Učitel s dobrou odbornou přípravou podcení obtížnost učiva, jeho výklad je povrchní, neodhaluje logické souvislosti a vede k formalismu. Došlo k podcenění metodické složky př́pravy. Druhým extrémem je učitel, který detailně propracuje přípravu po stránce metodické, ale bez hlubšího pochopení látky. Podcení tedy složku odbornou.

Podle Obsta (2002) je práce na přípravě náročnou myšlenkovou činností, při které si učitel opakovaně promítá v mysli celou vyučovací jednotku, zároveň okamžitě provádí její úpravy tak, aby odpovídala jeho záměru. Proto se podle Obsta naprostá většina učitelů připravuje písemně. Pracovní řád zaměstnance školy předpokládá jako samozřejmost důkladnou přípravu učitele na výuku, ale nepředepisuje její formu.

\subsubsection{UKÁZKY TYPŮ Př́PRAVY UČITELE NA VYUČOVACÍ JEDNOTKU}

Rys (1975) rozlišuje tři typy přípravy učitele na vyučovací jednotku. První typ nazývá „bleskovou přípravou“. Je vlastně odpovědí na otázky: Co? a Jak? Druhý typ přípravy odpovídá na otázky: Co již bylo?; Ceho chci dosáhnout?; Jak a čím toho dosáhnout?; Jaké bude mít tato hodina pokračováni? Třetí typ přípravy je nejnáročnější, jedná se o tzv. didaktickou analýzu učiva. V rámci didaktické analýzy učiva učitel nepromýšlí jen cíl, obsah učiva a vyučovací metody, ale zabývá se také zvláštními didaktickými hledisky (např. předchozími znalostmi žáků, způsobem práce, domácím úkolem apod.), výchovnými možnostmi, organizací vyučovací jednotky a jejím časovým rozvržením.

\footnotetext{
${ }^{7}$,What is it that my students will feel, know or be able to do at the end of the class (or classes) that they did not feel or know or were not able to do at the beginning of the class (classes)?" s. 259. Překlad autorka.
} 
Příprava podle Harmera (1992) je velmi podobná třetímu typu Rysovy přípravy. Harmer se navíc zabývá popisem tř́dy (popis žáků, jejich počet, věk; čas, doba trvání a frekvence hodin, podmínky a zázemí instituce) a možnými problémy (v organizaci hodiny, v pochopení úkolu, v porozumění nové látce). Harmer uvádí, že většina zkušených učitelů nepíše takto detailní a komplikované přípravy. Poukazuje ale na užitečnost takové přípravy pro nezkušené učitele. Dále pak v ní vidí zdroj velmi cenných informací pro analyzování hodin.

Hausenblas a kol. (2008) uvádí několik ukázkových lekcí, které mají sloužit jako inspirace pro učitele při práci podle ŠVP ${ }^{8}$. Struktura lekce vypadá takto: vzdělávací oblast, vzdělávací obor, délka, cíle na úrovni kompetencí, ke kterým daná vyučovací jednotka směřuje, cíle na úrovni očekávaných výstupư, průběh lekce, hodnocení.

Panasuk a Todd (2005) sestavují př́ípravu na základě čtyřstupřové strategie ${ }^{9}$ (FSLP). Učitel nejprve zformuluje cíle výuky, poté rozmyslí, jaký zadá na konci hodiny domácí úkol. Třetím stupněm je příprava rozvíjejících aktivit, které korespondují s cíli a dále napomáhají učení se žáků. V poslední fázi učitel rozmýšlí úlohy, jejichž pomocí u žáků zaktivizuje předchozí znalosti, které použijí při učení se nové látce. Hlavním cílem tohoto stupně je propojit u žáků předchozí znalosti s novými informacemi.

\subsubsection{VÝZKUMY VĚNOVANÉ PŘÍPRAVÁM}

Studie zabývající se př́ípravami učitelů a budoucích učitelů matematiky nejsou př́liš časté. Proto jsou v tomto oddíle zařazeny i některé výzkumy věnované přípravám učitelů a budoucích učitelů jiných předmětů.

Taylor (1970) analyzoval přípravy 261 učitelů literatury, př́rodních věd a zeměpisu. Ukázal, že učitelé se soustředí nejprve na obsah výuky, potom k němu vybírají a vymýšlejí situace, které by zaujaly žáky, a nakonec cíle, kterých by rádi ve výuce dosáhli. Znamená to tedy, že cíle, i když jsou velmi důležité, nemusí být vždy stanoveny na začátku.

Zahorik (1975) požádal 194 učitelů různých předmětů od 1. po 3. stupeň školy (z toho 51 učitelů přírodovědných a technických předmětů, matematiky a cizích jazyků), aby popsali postup, jakým tvoří př́pravu. Na základě analýzy těchto postupů vytvořil následující kategorie: cíl, obsah, aktivity žáků, diagnostika, hodnocení, instrukce a organizace. Zjistil, že $81 \%$ učitelů staví svoji přípravu na aktivitách žáků, $51 \%$ na obsahu výuky a $28 \%$ na cílech výuky.

Tochon (1989) zkoumá výpovědi učitelů francouzštiny 2. stupně základní školy, jež se týkají jejich způsobu př́pravy na výuku. Analyzuje je pomocí šesti „témat“, která vycházejí z literatury věnované přípravám. Jde o témata, nad kterými učitelé často přemýšlejí při plánování výuky: obtížnost plánování a nedostatečnost teorií o př́ípravě výuky, volba výukových metod, adaptace na stále se měnící podmínky, typy a zpo̊soby plánování výuky, tendence k rutině, improvizace. Výzkum byl prováděn formou částečně řízeného rozhovoru s pěti ženevskými učiteli 12-15letých žáků. Jednalo se o zkušené učitele s různými pedagogickými př́istupy. Cílem studie bylo zmapovat principy a zvyky učitelů při plánování výuky i významy termínu „plánování/připravování“ výuky tak, jak je vnímají učitelé. Ukázalo se, že tvorba přípravy je složitý proces. Učitel neustále balancuje mezi teorií a praxí, organizovaností a kreativitou, přísností a uvolněností, intelektuální rovinou a rovinou afektivní, technickým faktorem a faktorem lidským.

\footnotetext{
${ }^{8}$ Školní vzdělávací program.

${ }^{9}$ FSLP strategy $=$ Four Stages of Lesson Planning strategy.
} 
Ward, Anhalt a Vinson (2003) prováděli výzkum mezi 31 budoucími učiteli matematiky na 1 . stupni, kteří právě procházeli kurzem elementární matematiky ${ }^{10}$. Cúlem bylo zkoumat a zdokumentovat jejich úvahy při přípravě výuky matematiky. V průběhu semestru budoucí učitelé tř̌ikrát odevzdávali př́ipravy na hodiny. Výzkumníci vybrali několik tematických celků, budoucí učitelé měli týden na sepsání př́ípravy na hodinu tak, aby výuka byla co nejvíce efektivní, tj. aby žáci výuce co nejlépe porozuměli. Po týdnu diskutovali své př́ípravy ve skupinách a měli za úkol společně vytvořit ideální př́ipravu. Na konci semestru ještě každý vytvořil závěrečnou př́pravu. Výzkumníci následně plány analyzovali pomocí modelu pěti matematických reprezentaci ${ }^{11}$ a zjištovali, jaké jsou trendy v jejich používání. Ukázalo se, že v přípravách převládala jazyková reprezentace. Podle autorů studie přispívá využívání všech pěti matematických reprezentací k efektivnímu plánování výuky a žákům usnadňuje porozumění. Navrhují tedy zařadit práci s modelem pěti matematických reprezentací do vzdělávacího programu budoucích učitelů matematiky na 1 . stupni.

Zajímavý výzkum provedli Panasuk a Todd (2005), kteří porovnávali přípravy na hodiny s průběhem těchto hodin. Provedli faktorovou analýzu efektivity příprav na výuku, které byly sestaveny na základě strategie FSLP. Výzkumu se zúčastnilo 39 učitelů matematiky na 1. stupni základní školy, kteří absolvovali školení FSLP. Během jednoho školního roku odevzdali 261 př́iprav. Tyto přípravy byly analyzovány pomocí hodnotící tabulky vytvořené na základě strategie FSLP a na základě pozorování byly porovnávány s reálným průběhem hodiny. Výzkum ukázal, že přípravy vytvořené strategií FSLP napomohly k vyššímu stupni koherence mezi přípravou a skutečným průběhem hodiny.

Mutton, Hagger a Burn (2011) zkoumali, co se britští studenti učitelství učí o plánování výuky a jak se jejich pohled na plánování mění v průběhu prvních tř́ let praxe. Data získali pozorováním 17 studentů - učitelů angličtiny, matematiky a přírodních věd - a následně též částečně strukturovanými rozhovory s nimi. Po každé odučené hodině zjištovali, co si učitelé myslí o své přípravě na hodinu, jak průběh hodiny hodnotí. Autoři zdůrazňují, že schopnost plánovat výuku nelze naučit na univerzitě. Ve srovnání se zkušenými učiteli studentům chybí detailní znalosti prostředí, ve kterém se pohybují - specifika žáků a jejich chování, specifika tř́dy. Z výzkumu vyplývá, že začínající učitelé se učí „jak plánovat" v průběhu prvních let praxe. Autoři navrhují opětovné zavedení spolupráce čerstvých absolventů učitelství s uvádějícími učiteli. Přínos vidí především ve společném vytváření plánů a vzájemných hospitacích v hodinách.

Při plánování se učitelé dozvídají řadu nových informací o učení a při výuce se učí lépe plánovat. (Mutton, Hagger, Burn, 2011)12

V našem článku se zaměřujeme na přípravy, které si učitel vytváří, protože sám cítí potřebu je mít. Nezabýváme se případem, kdy učitelé mají předepsáno vnějšími institucemi, co musí do př́ipravy zařadit. Teoretickým rámcem výzkumu je TDSM, konkrétně analýza a priori. V první fázi zjištujeme, které části příprav považují za nutné všichni, nebo aspoň většina zkoumaných učitelů, a ve kterých částech se liší. Sledujeme rozdíly v těchto charakteristikách u učitelů 1. a 2. stupně základní školy a u budoucích učiteli̊ matematiky. Ve druhé fázi pracujeme s konkrétními

\footnotetext{
${ }^{10}$ Elementary mathematics course.

${ }^{11}$ Model pěti matematických reprezentací podle (Lesh, Post, Behr, 1987), jejichž prostřednictvím probíhá matematická komunikace mezi učitelem a žáky. Jde o reprezentaci konkrétní (manipulativní), jazykovou, symbolickou, obrázkovou a obsahovou (týkající se reálných životních situací).

12 "It is through planning that teachers are able to learn about teaching and through teaching that they are able to learn about planning." s. 413. Překlad autorka.
} 
př́pravami učitelů a budoucích učitelů matematiky. Provádíme srovnání s první fází výzkumu a porovnáváme přípravy zkušených učitelů s př́pravami studentů učitelství matematiky.

\section{PRVNí FÁZE VÝZKUMU}

Cílem první fáze výzkumu bylo analyzovat rozdíly mezi tím, co je zařazeno do analýzy a priori v teorii didaktických situací v matematice a skutečností v praxi učitelů. Dále jsou zde shrnuty pohledy učitelů na jednotlivé složky analýzy a priori tak, jak jsou v TDSM zařazeny.

\subsection{Metodologie}

Pro první fázi výzkumu jsme si kladli tyto výzkumné otázky:

- Jaké informace považují učitelé matematiky za důležité a zařazují je do své př́pravy na hodinu?

- Které složky analýzy a priori učitelé matematiky zařazují do svých příprav a které považují za zbytečné?

- Které složky učitelé v analýze a priori postrádají?

- Objeví se rozdíly v př́ípravách učitelů a budoucích učitelo̊?

K získání dat potřebných pro studii jsme sestavili dotazník. Dotazník obsahoval základní údaje o učiteli, tedy pohlaví, stupeň školy a délku praxe. V dotazníku jsou použity otázky s otevřenou odpovědí (otázky 1, 4 a 5) i uzavřenou odpovědí (otázky 2 a 3); použili jsme čtyřbodovou škálu. U všech otázek byl nechán respondentům prostor pro vlastní komentář či doplnění. Dotazníky byly rozesílány v elektronické i papírově podobě.

Nyní se podrobněji podíváme na jednotlivé otázky dotazníku.

- Otázka 1: Připravujete se na hodinu písemně?

Vzhledem k tomu, že u každého dotazníku byla známa délka praxe respondenta, umožňuje tato otázka také zjistit, zda a jak vytváření př́ipravy závisí na délce praxe. Předpokládali jsme, že zkušení učitelé písemnou přípravu využívají méně než začínající učitelé.

- Otázka 2: Co vaše př́prava obsahuje (at’ písemná či jiná)?

Tato otázka se skládá z pěti podotázek, první čtyři jsou vlastně složky analýzy a priori: téma hodiny, cíl hodiny, fáze hodiny a časové rozvržení, rozbor jednotlivých aktivit - tato složka je dále rozčleněna do osmi podotázek: způsob práce, pomůcky, které budete potřebovat, pomůcky, které budou potřebovat žáci, předchozí znalosti, postoje a reakce žáků, překážky, chyby a možné problémy, které se mohou u žáků objevit, správné strategie řešení, které mohou žáci použít, nesprávné strategie řešení, které mohou žáci použít. Zajímalo nás, jakou důležitost učitelé jednotlivým složkám přisuzují. Tuto informaci jsme získali na základě čtyřbodové škály odpovědí, ze které učitelé vybírali. V páté podotázce jsme nechali učitelům prostor, aby uvedli další složky přípravy, které náš dotazník neobsahuje. Zde jsme zjištovali, zda považují analýzu a priori za úplnou. 
Zde jsme předpokládali výrazný rozdíl mezi začínajícími a zkušenými učiteli.

- Otázka 4: Srovnáváte po hodině jeji skutečný průběh s vaši př́pravou? Pokud ano, co podle vás takové srovnání přináši vám učiteliom, a co žákiom?

Pomocí čtvrté otázky jsme zjištovali, zda učitelé provádějí po skončení výuky analýzu a posteriori.

- Otázka 5: Využiváte přípravy, které jste použili dřive? Pokud ano, jakou část můžete použit více méně bez změn, a jakou většinou upravujete a proč?

Vycházeli jsme z předpokladu, že pokud učitelé použivají přípravu v další práci, považují ji za vhodnou a kvalitní, at ve stávající podobě, nebo po úpravách a doplněních vycházejících z jejich stále se rozšiřující zkušenosti.

\subsection{VÝZKUMNÝ VZOREK}

Abychom získali pestrý vzorek učitelů, a tím i různé pohledy na přípravu, oslovili jsme učitele různých stupňů škol, kteř́i mají praxi od 4 do 30 let, i budoucí učitele matematiky pro 2. a 3. stupeň škol. Část respondentů jsme oslovili emailem, část osobně. Osobně jsme oslovili své kolegy, své bývalé učitele, učitele, které známe z dalšího vzdělávání učitelů, a studenty. Dále jsme elektronicky rozesílali dotazník na školy. Sledovali jsme, aby byli zastoupeni učitelé různých stupňů škol a budoucí učitelé matematiky. Takto jsme oslovili 100 respondentů. Získali jsme 31 vyplněných dotazníků. Zjistili jsme, že důvodem poměrně malé návratnosti je fakt, že učitelé jsou v dnešní době přehlceni žádostmi o vyplnění různých dotazníků a při velkém časovém vytížení v mnoha případech žádosti ignorují, případně odpovědí, že bohužel nemají čas dotazník vyplnit. Z reakcí některých učitelů usuzujeme, že mnohdy považují přípravu na výuku za osobní záležitost a nepřejí si ji s námi sdílet. Respondenti nebyli s TDSM ani s analýzou a priori seznámeni. Experimentu se zúčastnilo 31 učitelů a budoucích učitelů: 14 učitelů 1. stupně základní školy (první experimentální skupina), 10 učitelů 2. stupně základní školy (druhá experimentální skupina), 7 studentů učitelství matematiky na PedF UK v Praze (třetí experimentální skupina). Cílem srovnání bylo zmapovat rozdíly u učitelů podle stupně škol, na kterém učí, a rozdíly mezi studenty - budoucími učiteli matematiky a učiteli z praxe.

\subsection{VÝSLEDKY}

Nejprve se budeme zabývat celkovými výsledky, ve druhé části porovnáním výsledků jednotlivých experimentálních skupin.

\subsubsection{Celkové vyHodnocení}

Výsledky pro první dvě otázky jsou v tabulce 1. 
Tab. 1: Výsledky první fáze výzkumu

\begin{tabular}{|c|c|c|c|c|c|}
\hline Otázka & Ano, vždy & Téměř vždy & Zř́idka & Nikdy & Bez odpovědi \\
\hline $\begin{array}{l}\text { 1. Připravujete se na } \\
\text { hodinu písemně? }\end{array}$ & 16 & 9 & 6 & 0 & 0 \\
\hline \multicolumn{6}{|c|}{ 2. Co vaše př́iprava obsahuje (at’ písemná či jiná)? } \\
\hline 2.1. Téma hodiny & 21 & 8 & 2 & 0 & 0 \\
\hline 2.2. Cíl hodiny & 17 & 7 & 5 & 2 & 0 \\
\hline $\begin{array}{l}\text { 2.3. Fáze hodiny, } \\
\text { časové rozvržení }\end{array}$ & 8 & 13 & 8 & 2 & 0 \\
\hline \multicolumn{6}{|l|}{ 2.4. Jednotlivé aktivity } \\
\hline $\begin{array}{l}\text { 2.4.1. Způsob práce } \\
\text { (individuální, } \\
\text { skupinová apod.) }\end{array}$ & 15 & 14 & 2 & 0 & 0 \\
\hline $\begin{array}{l}2.4 .2 \text { Pomůcky, } \\
\text { které budete } \\
\text { potřebovat }\end{array}$ & 12 & 9 & 10 & 0 & 0 \\
\hline $\begin{array}{l}\text { 2.4.3. Pomůcky, } \\
\text { které budou } \\
\text { potřebovat žáci }\end{array}$ & 13 & 10 & 5 & 1 & 0 \\
\hline $\begin{array}{l}\text { 2.4.4. Předchozí } \\
\text { znalosti }\end{array}$ & 11 & 10 & 6 & 4 & 0 \\
\hline $\begin{array}{l}2.4 .5 . \text { Postoje } \\
\text { a reakce žáků }\end{array}$ & 1 & 11 & 7 & 11 & 1 \\
\hline $\begin{array}{l}\text { 2.4.6. Překážky, } \\
\text { chyby a možné } \\
\text { problémy, které se } \\
\text { u žáků mohou } \\
\text { objevit }\end{array}$ & 3 & 10 & 13 & 5 & 0 \\
\hline $\begin{array}{l}\text { 2.4.7. Správné } \\
\text { strategie řešení, } \\
\text { které mohou žáci } \\
\text { použít }\end{array}$ & 5 & 14 & 9 & 3 & 0 \\
\hline $\begin{array}{l}\text { 2.4.8. Nesprávné } \\
\text { strategie řešení, } \\
\text { které mohou žáci } \\
\text { použít }\end{array}$ & 4 & 7 & 12 & 7 & 0 \\
\hline
\end{tabular}

Otázka 3: Kolik času trávíte průměrně př́pravou na jednu hodinu 213 $^{13}$

Nejvíce respondentů (12) se připravuje 15 až 30 minut, nejméně (3) jich přípravu zvládne do 15 minut. Deseti respondentům př́íprava trvá 30 až 45 minut; více než 45 minut stráví př́pravou na jednu vyučovací hodinu 6 respondentů.

Otázka 4: Srovnáváte po hodině jeji skutečný průběh s vaší př́pravou? Pokud ano, co podle vás takové srovnání přináši vám, učitelům, a co žákům?

Většina učitelů odpověděla kladně, pouze jeden učitel napsal, že „necítí potřebu“. Odpovědi jsme rozdělili do dvou skupin. V první skupině odpovědí (A1, 6 respon-

\footnotetext{
${ }^{13}$ Respondenti vybírali z těchto čtyř možností: 0-15 minut, 15-30 minut, 30-45 minut, 45 minut a více.
} 
dentů) mluví učitelé a budoucí učitelé pouze o přínosu pro ně samotné, v druhé (A2, 13 respondentů) o př́nosu jak pro ně, tak pro žáky. Zbývající odpovědi byly př́liš stručné, proto v žádné ze skupin nefigurují.

A1: „Ano, rozšiřuje mi to soubor žákovských řešení, zpřesňuje moje očekávání (častěji jsou tím pádem naplněna).“

A2: „Snažím se vždy po hodině, pokud to čas dovolí, zjistit, kde jsem se v hodině zbytečně zdržel a kde jsem případně př́liš spěchal. Žákům tato sebereflexe může usnadnit pochopení učiva a mne vede $\mathrm{k}$ tomu, abych se přizpơsobil jejich potřebám a tempu."

Otázka 5: Využiváte př́pravy, které jste použili dřive? Pokud ano, jakou část müžete použít více méně bez změn a jakou většinou upravujete a proč?

Odpovědi na tuto otázku jsme rozdělili do čtyř skupin (B1-B4). První skupinu (B1, 7 respondentů) tvoří odpovědi všech studentů učitelství, kteří jednomyslně odpověděli, že ještě moc př́prav nemají a nemohou na tuto otázku odpovědět. Druhou skupinou (B2, 13 respondentů) jsou učitelé, kteří odpověděli, že př́ipravy opakovaně používají, třetí skupinou (B3, 4 respondenti) jsou učitelé, kteří je znovu nepoužívají, a čtvrtou (B4, 7 respondentů) ti, kteří je použijí pouze výjimečně.

B2: „Př́pravy předešlé používám, mám tam poznámky, co vylepšit, víc se asi využije výklad, ale i ten si člověk upraví podle dětí ve třídě."

B3: „Nevyužíiám, protože jsem ještě nikdy první tř́ídu neučila. Ale pokud bych ji někdy v budoucnu učila, tak po zkušenostech z jiných ročníků vím, že se to nikdy nedalo, naopak využití staré př́pravy bylo vždy kontraproduktivní, žádné dvě třídy nereagovaly na stejnou př́pravu stejně."

\subsubsection{POROVNÁNí ODPOVĚdí V EXPERIMENTÁLNÍCH SKUPINÁCH}

Nyní se podíváme, jak vypadalo rozvržení odpovědí v jednotlivých skupinách. Výsledky třetí experimentální skupiny - studentů učitelství pro 2. a 3. stupeň Z $\breve{S}-$ zde neuvádíme. Jejich odpovědi jsou ovlivněny velmi malou nebo žádnou zkušeností z učitelské praxe. Vyplývá to i z jejich komentářrou, např. (k otázce 2.4.8.): „Nejsem zatím schopna většinou odhadnout."

V dalším textu budeme tedy porovnávat odpovědi první a druhé experimentální skupiny. Připomeňme si, že první experimentální skupinu tvořilo 14 učitelů 1 . stupně ZS̆, druhou experimentální skupinu 10 učitelů 2. stupně ZŠ. Vzhledem k různému počtu respondentů ve skupinách jejich odpovědi uvádíme v procentech. Porovnávali jsme vždy součet odpovědí ano, vždy a téměr vždy. Otázky jsme rozdělili do dvou částí, C1 a C2. Do C1 jsme zařadili ty otázky, kde se v odpovědích vyskytovaly mezi první a druhou experimentální skupinou rozdíly 20 \% nebo větší, do části C2 ostatní otázky.

\section{A) Část $C 1$}

Největší rozdíly (20 \% a více) mezi první a druhou experimentální skupinou jsme zaznamenali u těchto otázek: 2.4.2. Pomůcky pro učitele, 2.4.3. Pomůcky pro žáky, 2.4.4. Předchozí znalosti, 2.4.5. Postoje a reakce žáků, 2.4.6 Překážky, chyby a možné problémy, 2.4.7. Správné strategie řešení, 2.4.8. Nesprávné strategie. Učitelé druhého stupně se těmito položkami zabývají častěji než učitelé na prvním stupni ZS̆. Vysvětlujeme si to různou povahou a obtížností učiva. 
Odpovědi na následující otázky byly v obou skupinách srovnatelné, tj. rozdíl v součtu odpovědí ano, vždy a téměř vždy byl menší než $20 \%$ : 1. Připravujete se na hodinu písemně? 2.1. Téma hodiny, 2.2. Cíl hodiny, 2.3. Fáze hodiny a časové rozvržení, 2.4.1. Způsob práce, 3. Kolik času strávíte průměrně prŕípravou na jednu hodinu? ${ }^{14}$ Srovnatelné odpovědi jsme získali i na otázky 4. a 5. Vysvětlujeme si to tím, že se jedná o obecnější / formálnější složky přípravy, které jsou na prvním i druhém stupni podobné.

\subsection{Porovnání S ANALÝZOU A PRIORI PODLE TDSM}

Nyní porovnáme přípravy učitelů a budoucích učitelů a analýzu a priori podle TDSM.

Nejprve se podíváme, co je pro ně společné. Budeme při tom vycházet z otázky 2 , protože položky v této otázce jsou vlastně složky analýzy a priori podle TDSM. $\mathrm{V}$ případě, že většina učitelů a budoucích učitelů odpověděla na podotázky v této otázce ano, vždy a téměr vždy, považujeme položku za společnou. Z dotazníků vyplývá, že většina respondentů do svých příprav uvádí téma hodiny, cíl hodiny, fáze hodiny, časové rozvržení. Zamýšlejí se nad způsobem práce v hodině, pomůckami, předchozími znalostmi a správnými strategiemi (i když ne ve stejném rozsahu).

Nyní se zaměříme na ty složky analýzy a priori, které učitelé a budoucí učitelé ve svých přípravách považují za zbytečné, resp. je nepoužívají. V př́ípadě, že většina odpověděla zř́dka a nikdy, usuzujeme, že položku považují za nepodstatnou. Jedná se o položky postoje a reakce žáků, překážky, chyby a možné problémy, nesprávné strategie řešení.

V otázce 2.5. mohli respondenti napsat, jaká složka přípravy v dotazníku chybí (a přitom ji považují za důležitou). Na otázku odpovědělo celkem 11 učitelů a budoucích učitelů. Odpovědi jsme rozdělili do dvou skupin, D1 a D2 (u každé uvádíme typická vyjádření respondentů):

D1 - Konkretizace námi navržené př́pravy, jeji uvedení do praxe, jako např.:

- „rozpracování jednotlivých aktivit: motivační rozcvičky, úvodní problémová úloha, matematické rébusy/hry, shrnutí učiva,"

- „testy, písemky, aktuální problémy ze života, kde se dá použít matematika, .. . “

D2 - „Nové“ složky př́pravy, které se v naší přípravě neobjevily:

- „klíčové kompetence (které rozvíjím),“

- „datum a číslo hodiny od začátku roku, očekávání, která si zapisuji na stránku, kam pak budu psát průběh hodiny; očekávání někdy k celé třídě, někdy k jednotlivcům."

\section{DRUHÁ FÁZE VÝZKUMU}

První fáze výzkumu neumožnila získat hlubší vhled do problematiky. Potřebovali jsme analyzovat přímo vytvořené přípravy, a to nejlépe na společné téma. Proto jsme připravili druhou fázi výzkumu a kladli jsme si tyto otázky:

\footnotetext{
${ }^{14}$ Vyhodnocení této otázky: sloučili jsme časy do dvou časových úseků (0-30 minut a 30 a více minut). U učitelů druhého stupně připadlo $50 \%$ odpovědí do časového úseku 0-30 minut a $50 \%$ do úseku 30 a více minut. U učitelů prvního stupně $57 \%$ do časového úseku 0-30 minut a $43 \%$ do úseku 30 a více minut. Tyto výsledky považujeme za srovnatelné.
} 
- Zařadí učitelé a studenti učitelství do svých konkrétních příprav složky, které byly uvedeny v dotazníku v první fázi výzkumu?

- Jaké jsou rozdíly v přípravách studentů učitelství a učitelo̊?

- Lze vytvořit nějakou kategorizaci příprav (typologie příprav podle převažujících složek analýzy a priori)?

Pro druhou fázi experimentu jsme použili úlohu, kterou by učitelé a budoucí učitelé mohli zařadit do výuky a vytvořili pro ni př́pravu. Př́pravy jsme pak porovnávali s odpověd’mi na otázky v dotazníku z první fáze výzkumu.

\subsection{VÝBĚR ÚLOHY}

Abychom z př́prav získali co nejvíce informací, stanovili jsme tři kritéria výběru úlohy. Chtěli jsme, aby úloha byla neobvyklá, tj. taková, se kterou se žáci ani učitelé nesetkají běžně v učebnicích. Dále jsme požadovali, aby práce s ní nebyla limitována věkem žáků, aby ji bylo možné použít v různých ročnících. Nakonec jsme chtěli, aby úloha poskytovala velký prostor kreativitě učitelů, tj. nabízela více správných strategií řešení, dala se zařadit do různých tematických celků, umožňovala různé formy práce.

Ulohu, která podle našeho názoru splňuje všechna výše uvedená kritéria, jsme vybrali z Diofantova spisu Aritmetika. Jedná se o úlohu číslo tři z Knihy první.

V následujícím textu provedeme analýzu a priori této úlohy a seznámíme se s ní podrobněji.

\subsection{AnalÝza a priori Úlohy Diofant, Kniha PRVNí, Úloha Č. 3}

Rozdělte dané číslo na dvě části tak, aby se větši z nich rovnala trojnásobku menší, zvětšenému o čtyři. ${ }^{15}$

- Charakter zadání: Úloha může být zadána vizuálně (napsaná na tabuli, v pracovním listu) nebo slovně (učitel úlohu žákům nadiktuje). Úlohu můžeme zadat jako text nebo ve formě rovnice. Touto formou zadání ale ztratí částečně svůj potenciál, kterým je přepis mluveného/psaného slova do jazyka matematiky.

- Znalosti potřebné ke správnému pochopení zadání

* Matematické: trojnásobek, zvětšit o čtyřri.

* Všeobecné: menší a větší část, rozdělit dané číslo.

- Obtíže v chápání zadání: Domníváme se, že formulace zadání je na porozumění poměrně složitá. $V$ jednom souvětí je hned několik informací: je dáno číslo, úkolem je rozdělit je na dvě nestejné části, větší část má být rovna trojnásobku menší části zvětšenému o čtyři. Pro žáky může být obtížné všechny tyto informace zaznamenat a pochopit. Zvlášt formulace „... trojnásobku zvětšenému o čtyři““ by mohla být problematická.

\footnotetext{
15 „Diviser un nombre donné en deux parties, telles que la plus grande soit égale au triple de la plus petite, plus quatre unités." Překlad autorka. (Fermat, 1853, s. 47, Kniha první, úloha třetí.)
} 
- Tematický celek, do kterého by se úloha dala zařadit: Úloha by se dala zařadit už do 6. ročníku, a to jako součást tematického celku Č́slo a proměnná. V 7. ročníku by mohla být uvedena v rámci tematického celku Lineární rovnice, na střední škole pak v 1. ročníku, když se probírají různé typy rovnic.

- Cíl úlohy: Matematický: žáci mají za úkol rozdělit dané číslo na dvě nestejné části. Podmínkou je daný vztah mezi těmito částmi: větší z nich má být rovna trojnásobku menší, zvětšenému o čtyři.

Didaktický: žáci se učí matematizovat slovně zadanou úlohu, najít vhodnou řešitelskou strategii.

- Čas, který bude úloze věnován: Záleží na učiteli, jakým způsobem úlohu zadá (může zadat konkrétní číslo, které mají žáci rozdělit, konkrétní číselný obor, ve kterém budou řešit), a na věku žáků. Odhadujeme polovinu vyučovací hodiny.

- Způsob práce: Domníváme se, že pro řešení úlohy je vhodná práce ve dvojicích nebo ve skupinách. Úloha je podle našeho názoru neobvyklá a někteří žáci by mohli mít při individuální práci problém s pochopením zadání. Ve skupině by se tyto obtíže mohly odstranit už na začátku. Při sestavování skupin je ale třeba vzít $\mathrm{v}$ úvahu nebezpečí, která s sebou skupinová práce přináší, např. zapojení rychlejších a pomalejších žáků.

- Pomůcky: Sešit, tužka, pro větší čísla kalkulačka. Zajímavý by mohl být i počítač, konkrétně program Excel, kam by mohli žáci rovnici zadat a hledat různá řešení, ale to bychom navrhli až po vyřešení „na papír".

- Proměnné: V úloze najdeme dva typy proměnných: kognitivní didaktické a formulační proměnné.

- Kognitivni didaktické proměnné [dané číslo] - můžeme zadat přímo konkrétní číslo (např. číslo 12, pak úlohu mohou řešit i děti na 1. stupni).

[dvě] - můžeme dělit i na tři, čtyři a více částí, pak už je ale úloha mnohem obtížnější a obtížněji řešitelná systematickým experimentováním nebo metodou pokus-omyl.

[trojnásobek] - když zvolíme vyšší násobek, opět bude úloha obtížněji řešitelná systematickým experimentováním nebo metodou pokus-omyl. [zvětšenému] - můžeme nahradit za „zmenšenému“. Podle studie (Nesher, Hershkovitz, Novotná, 2003) dávají řešitelé přednost zvětšování před zmenšováním, úloha by se tedy žákům mohla zdát obtížnější.

[čtyři] - pokud nahradíme jiným číslem, např. desetinným, bude úloha obtížnější.

- Formulační proměnné: [rozdělte], [větší], [menši], [části]

- Předchozí znalosti: Č́selné obory N a Z, dělitelnost, pojmy násobek, menší a větší část.

- Postoje a reakce žáků: Předpokládáme, že se objeví na začátku žáci, kteří ihned nějaké řešení uhodnou, a žáci, kteří si nebudou vědět rady. Domníváme se, že je může překvapit obtížná srozumitelnost zadání a fakt, že správné řešení nezískají snadno. 
- Postoje a reakce učitelů: Domníváme se, že se úloha bude líbit kreativním učitelưm díky možnostem použití, které nabízí. Mohou ji uvést v různé podobě, s ohledem na věk a schopnosti žáků.

- Správné strategie řešení: Označme dané číslo jako $a$. Budeme pracovat v oboru celých čísel, tedy ${ }^{16} a \in \mathrm{Z}$.

Máme rozdělit číslo $a$ na dvě části, označme je $b$ a $c$.

Potom

$$
a=b+c, \text { kde např. } b>c,
$$

podle zadání

$$
b=3 c+4 .
$$

Dosadíme za $b$ :

$$
a=3 c+4+c
$$

po úpravě

$$
a=4 c+4 .
$$

Je patrné, že pokud budeme hledat celočíselná řešení, číslo a musí být dělitelné čtyřmi.

Úloha je řešitelná několika strategiemi:

a) Řešeni diofantovské rovnice: Naším úkolem je dané číslo rozdělit. Vyjádříme tedy části $b$ a $c$ pomocí daného čísla $a$. Vycházíme přitom z výše uvedených vztahů (1) a (2).

Dané číslo $a$ rozdělíme na dvě části, které můžeme zapsat jako

$$
c=\frac{a}{4}-1, \quad b=\frac{3 a}{4}+1 .
$$

Pokud chceme navíc, aby řešení bylo celočíselné, musí být a dělitelné čtyřmi. Znalosti: neznámá, parametr, úpravy lineárních rovnic.

Možné obtǐže: chybné převedení textu zadání do matematického jazyka, chybné vyjádření jednotlivých částí, nesprávné dosazení.

b) Systematické experimentování: Vyjdeme opět ze vztahů (1) a (2). Budeme hledat celočíselná řešení a postupně se pokusíme odvodit obecný předpis pro obě části, které vzniknou rozdělením čísla $a$. Začneme tím, že za číslo $a$ budeme dosazovat konkrétní hodnoty. Ze vztahu (2) vyplývá, že pokud chceme hledat celočíselná řešení, číslo a musí být dělitelné čtyřmi.

Sestavíme tabulku 2.

Tab. 2: Hledání obecného předpisu řešení úlohy

\begin{tabular}{|c|c|c|}
\hline$a$ & $b$ & $c$ \\
\hline 4 & 4 & 0 \\
\hline 8 & 7 & 1 \\
\hline$a_{n}$ & $a_{n}-n$ & $n$ \\
\hline
\end{tabular}

$$
n=\frac{a}{4}-1 \text {. }
$$

\footnotetext{
${ }^{16}$ Jedná se o diofantovskou rovnici, proto řešíme v oboru celých čísel.
} 
V posledním řádku tabulky vidíme řešení.

Znalosti: násobky čísla 4, základní početní operace, zobecnění vztahu.

Možné obtǐže: nepřehledný zápis $\mathrm{v}$ tabulce, dílčí chyba ve výpočtu některé z částí, chybné zobecnění vztahů.

c) Metoda pokus-omyl: Tuto metodu lze použít pouze $\mathrm{v}$ př́ípadě, že za číslo $a$ dosazujeme konkrétní hodnoty. $\mathrm{K}$ obecnému vyjádření touto cestou pravděpodobně nedojdeme. Budeme hledat celočíselná řešení.

Zvolme $a=12$.

Kdyby menší část byla rovna 1 , větší by byla rovna 11 , ale $3 \cdot 1+4 \neq 11$.

Kdyby menší část byla rovna 2 , větší by byla rovna $10,3 \cdot 2+4=10$, to je správně.

Č́slo 12 rozdělíme na čísla 2 a 10.

Znalosti: základní početní operace.

Možné obtǐze: aritmetická chyba ve výpočtu.

d) Graf: Vycházíme opět z podmínek (1) a (2). Je-li zadáno číslo $a$, máme určit čísla $b$ a $c$. Zapíšeme funkce, které vyjadřují závislosti hledaných hodnot $(b ; c)$ na zadané hodnotě $(a)$ :

$$
f_{1}: b=\frac{3 a}{4}+1 \quad f_{2}: c=\frac{a}{4}-1
$$

Pokud chceme navíc, aby řešení bylo celočíselné, musí být $a$ dělitelné čtyřmi. Sestrojíme grafy obou funkcí. Oba grafy můžeme zakreslit do jednoho obrázku a obě hledané hodnoty určit pro zadané $a$ z tohoto grafu.

Řešením jsou pro každé zadané $a$ příslušné hodnoty $b$ a $c$. Např́íklad pro $a=12$ je $b=10$ a $c=2$.

Znalosti: lineární funkce, sestrojení jejího grafu.

Možné obtǐže: nesprávné sestrojení grafu, nesprávná interpretace výsledku.

e) Obrázek (obdélník): Číslo a, které chceme dělit, můžeme reprezentovat obdélníkem rozděleným na části (obr. 2).

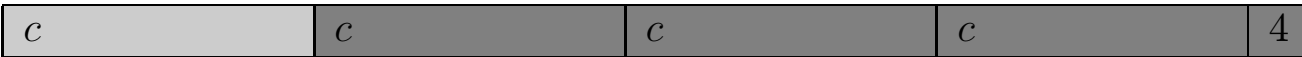

Obr. 2

Podle obrázku 2 vidíme, že část $c$ získáme, odečteme-li od čísla $a$ číslo 4 a výsledek vydělíme čtyřmi.

Znalosti: základní početní operace, převedení textu do matematického vyjádřnéí.

Možné obtíže: chyba v obecném zápisu výsledku, nesprávná vizualizace úlohy, chyby při provádění algebraických úprav.

\section{- Nesprávné strategie řešení}

„Vydělit třemi, odečíst čtyři $“$ 
Tato strategie vychází z nesprávného porozumění zadání. Úkolem žáků je rozdělit dané číslo na dvě části tak, aby se větší z nich rovnala trojnásobku té menší, zvětšenému o čtyři. Tedy

$$
\begin{aligned}
a & =b+c, \text { kde např. } b>c, \\
b & =3 c+4 .
\end{aligned}
$$

Někteři žáci by ale mohli díky nepozornému čtení dojít k jinému vztahu: větší část čísla by se rovnala trojnásobku menší části zvětšené o čtyři.

$$
b=3(c+4)
$$

- Hodnocení: Navrhujeme ohodnotit známkou 1 nebo příslušným bodovým ekvivalentem všechny úspěšné řešitele, ostatní ohodnotit pouze slovně.

\subsection{Metodologie}

Respondentům byla úloha zasílána $\mathrm{v}$ elektronické podobě s průvodním dopisem, kde byli požádáni o sestavení velmi podrobné přípravy na hodinu, při které by využili právě námi navrhovanou úlohu. Úlohu mohli podle potřeby upravit a použít v jakémkoli ročníku.

\subsection{VÝZKUMNÝ VZOREK}

Chtěli jsme porovnat př́pravy začátečníků a zkušených učitelů - expertů, a proto jsme oslovili nejen učitele matematiky, ale i studenty učitelství. Experimentu se zúčastnilo celkem 26 učitelů a budoucích učitelů: 16 studentů učitelství matematiky pro 2. a 3. stupeň školy z PedF UK v Praze a 10 učitelů matematiky. Studenti učitelství se výzkumu zúčastnili v rámci předmětu Didaktika matematiky a př́pravu odevzdali jako seminární práci. Učitele matematiky jsme oslovili osobně. Stejně jako v první fázi výzkumu jsme se často setkali s odmítnutím a odvoláním na velkou pracovní vytíženost. Proto se nám nepodařilo získat větší vzorek respondentů. Získali jsme dvě skupiny respondentů, lišící se délkou praxe: studenti většinou s praxí v řádu několika hodin $\mathrm{v}$ rámci studia, jeden student s praxí 1 rok a dva studenti s praxí 2 roky, a učitelé s praxí od 3 do 25 let. Cílem rozdělení bylo vzájemně porovnat př́pravy jednotlivých skupin a srovnat je s naší analýzou a priori.

Co se týče psaní příprav, je nutné vzít v úvahu, že studenti v rámci svých praxí odevzdávali minimálně dvě př́pravy na své hodiny ${ }^{17}$. To je mohlo ovlivňovat při psaní př́iprav v rámci našeho výzkumu. Na druhou stranu lze předpokládat, že i učitelé byli v průběhu svého učitelského studia k dělání př́íprav vedeni.

\footnotetext{
${ }^{17} \mathrm{~V}$ rámci praxe studenti odevzdávali jednu př́́pravu s následující strukturou: „Stanovení cílů; Popis činností, které budou žáci v průběhu výuky vykonávat, aby cílů dosáhli; Pojmenování výukových metod a forem, které jsou v rámci činností žáků použivány; Uvedení způsobu, jakým si ověříte, zda bylo cílů dosaženo; Definování didaktických pomůcek a techniky, které budou v rámci hodiny zapotřebí; Poznámky $\mathrm{k}$ vývoji hodiny: tyto poznámky slouží k zamyšlení se, jaké problémy mohou v průběhu výuky nastat a jak řešit situaci, kdy se hodina nebude vyvíjet podle plánu (např. je-li součástí hodiny práce s učebnicí, je důležité počítat s tím, že žáci učebnici mít nebudou apod.); Reflexe hodiny: po odzkoušení projektu odpovězte na následující otázky: Co se v hodině povedlo? Jaké problémy se $\mathrm{v}$ průběhu hodiny vyskytly? V čem je podle vašeho názoru žádoucí projekt hodiny změnit?"
} 


\subsection{VÝSLEDKY}

V této části nejprve porovnáme výsledky druhé fáze experimentu s výsledky první fáze experimentu. Poté se zaměříme na srovnání příprav studentů a učitelů a v závěru vytvoříme kategorizaci příprav na základě složek analýzy a priori.

\subsubsection{SROVNÁNí VÝSLEDKŮ OBOU FÁZí VÝZKUMU}

V každé př́ipravě, kterou jsme od respondentů obdrželi, jsme sledovali přítomnost nebo nepř́itomnost následujících třinácti složek (jejich rozsah a kvalitu jsme nesledovali): téma hodiny, cíl hodiny, fáze hodiny, časové rozvržení, způsob práce, pomůcky, předchozí znalosti, postoje a reakce žákůn, překážky, chyby a možné problémy, správné strategie řešení, nesprávné strategie řešení, způsob hodnocení.

Jedná se o složky analýzy a priori tak, jak byly uvedeny během první fáze výzkumu. Poslední z nich, způsob hodnocení, jsme právě na základě jejích výsledků do analýzy a priori přidali. Domníváme se, že jde o nedílnou součást plánování výuky, která ovlivňuje především výběr aktivity v hodině a způsob práce.

Na obr. 3 srovnáváme pomocí sloupcového grafu výsledky obou fází výzkumu. Vzhledem $\mathrm{k}$ různému počtu respondentů ve srovnávaných skupinách uvádíme výsledky v procentech, v tabulkách 3 až 13 také absolutní počty. Srovnáváme kladné odpovědi, tj. v druhé fázi experimentu přítomnost dané složky, v první fázi experi-

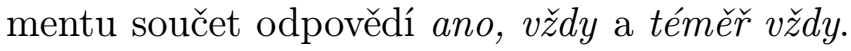

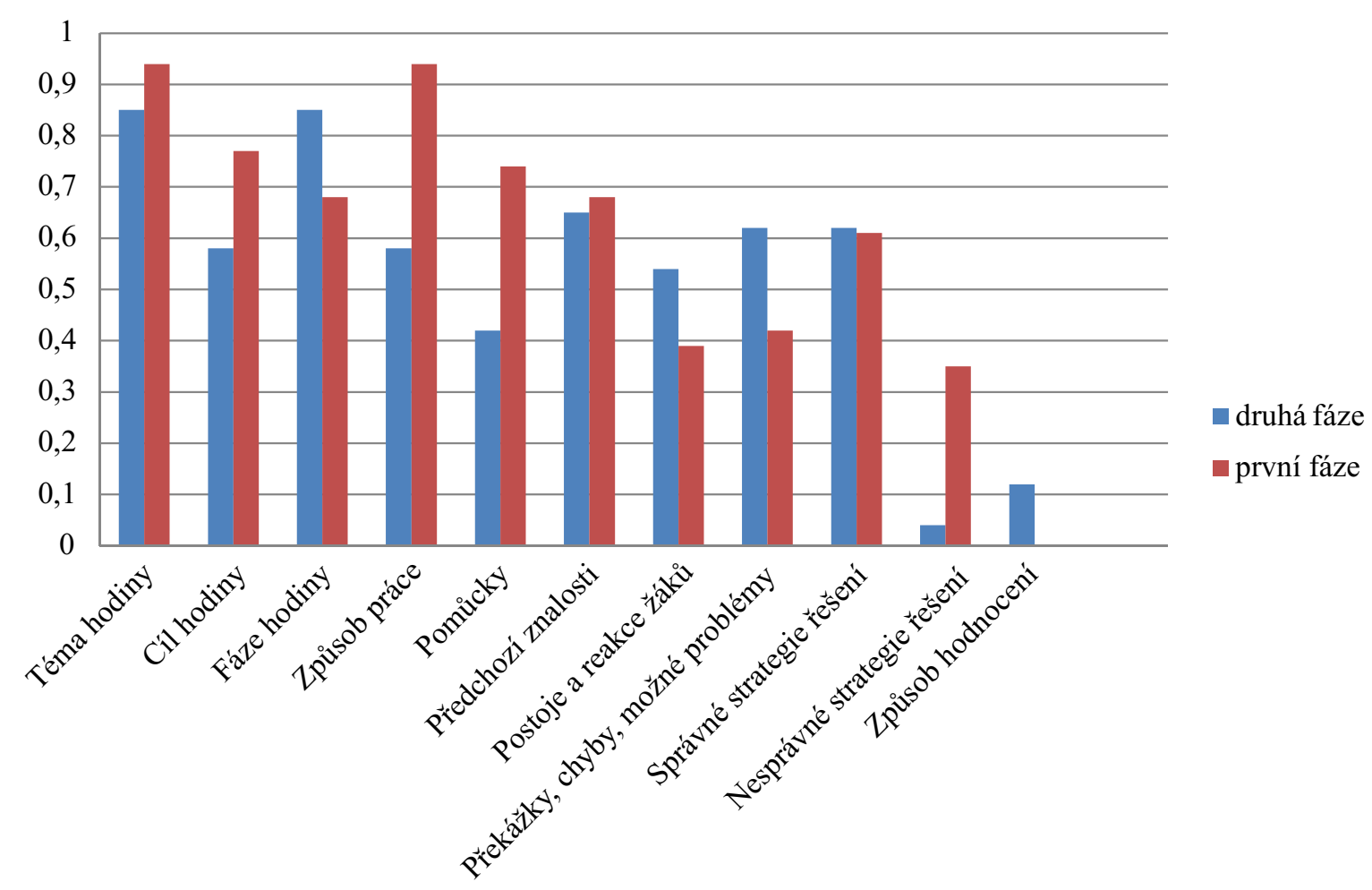

Obr. 3: Srovnání první a druhé fáze experimentu

Nyní se podrobněji podíváme na jednotlivé složky a srovnáme je s výsledky dotazníku první fáze výzkumu. Složky jsme rozdělili do tří skupin, podle míry odlišnosti. 
Tab. 3: Cíl hodiny

\begin{tabular}{|c|c|}
\hline První fáze & Druhá fáze \\
\hline $77 \%$ & $58 \%$ \\
\hline $24 / 31$ & $15 / 26$ \\
\hline
\end{tabular}

Jak uvádí např. Obst (2002) nebo Harmer (1992), každá hodina by měla mít stanovený cíl. Domnívali jsme se tedy, že cíl hodiny nalezneme ve většině příprav. I v dotazníku $77 \%$ respondentů odpovědělo, že jej do prŕprav zahrnují. Cíl hodiny byl ale zapsán jen v $58 \%$ analyzovaných příprav. Může to být způsobeno tím, že učitelé, případně studenti, necítí potřebu cíl zapisovat, že jej mají při tvorbě přípravy „v hlavě“. Nebo se spoléhají na to, že každá úloha má nějaký cíl, který je implicitně př́tomný v jejím zadání.

Tab. 4: Fáze hodiny

\begin{tabular}{|c|c|}
\hline První fáze & Druhá fáze \\
\hline $68 \%$ & $85 \%$ \\
\hline $21 / 31$ & $22 / 26$ \\
\hline
\end{tabular}

V dotazníku byla tato otázka spojena s otázkou časového rozvržení, v přípravách jsme sledovali tyto složky odděleně a zjistili jsme mezi nimi značné rozdíly. $68 \%$ respondentů v dotazníku uvedlo, že do svých příprav zaznamenávají fáze hodiny a časové rozvržení. V analyzovaných př́ipravách jsme rozfázování hodiny identifikovali v $85 \%$ př́padi̊. Rozdíl oproti první fázi je způsoben spojením složek fáze hodiny a časové rozvržení.

Tab. 5: Časové rozvržení

\begin{tabular}{|c|c|}
\hline První fáze & Druhá fáze \\
\hline- & $35 \%$ \\
\hline- & $9 / 26$ \\
\hline
\end{tabular}

Časové plánování výuky je velmi důležité, ale zároveň nesnadné. Zvlášt́ pro začínající učitele je těžké odhadnout, jak dlouho bude aktivita trvat. Pouze $35 \%$ učitelů a studentů ve svých přípravách provedlo časové odhady pro jednotlivé fáze hodiny.

Tab. 6: Způsob práce

\begin{tabular}{|c|c|}
\hline První fáze & Druhá fáze \\
\hline $94 \%$ & $58 \%$ \\
\hline $29 / 31$ & $15 / 26$ \\
\hline
\end{tabular}

Budou žáci pracovat jednotlivě? Ve dvojicích? Ve skupinách? Všichni společně? Odpovědi na tyto otázky si do přípravy zaznamenalo pouze $58 \%$ učitelů a studentů, v dotazníku to bylo $94 \%$ respondentů. Vysvětlujeme si to tím, že při vyplňování dotazníku si učitelé zř̌ejmě představovali běžnou vyučovací hodinu, a ne hodinu, 
kam zařadí nestandardní úlohu. Také je možné, že tuto otázku řeší podle typu úlohy a aktuální situace ve třídě až těsně před zadáním dané aktivity.

Tab. 7: Postoje a reakce žáků

\begin{tabular}{|c|c|}
\hline První fáze & Druhá fáze \\
\hline $39 \%$ & $54 \%$ \\
\hline $12 / 31$ & $14 / 26$ \\
\hline
\end{tabular}

Celkem 39 \% učitelů a budoucích učitelů v dotazníku odpovědělo, že se při tvorbě př́pravy zamýšlejí nad tím, jak budou žáci na danou aktivitu reagovat. Poznámku o postojích a reakcích žáků jsme v přípravách objevili dokonce v $54 \%$. Vysvětlujeme si to tím, že jsme zadali méně obvyklou úlohu, a učitelé i studenti se nad ní víc zamýšleli. Reakce žáků na učebnicové úlohy by pravděpodobně nezapisovali, snadněji je odhadnou, nebo ti zkušenější je už dopředu znají.

Tab. 8: Překážky, chyby a možné problémy

\begin{tabular}{|c|c|}
\hline První fáze & Druhá fáze \\
\hline $42 \%$ & $62 \%$ \\
\hline $13 / 31$ & $16 / 26$ \\
\hline
\end{tabular}

Touto problematikou se ve skutečných přípravách opět zabývalo více učitelů a studentů ( $62 \%$ ) než v dotazníku (42\%). Může to být rovněž zpưsobeno výběrem netypické úlohy. Při vyplňování dotazníku zřejmě učitelé a studenti odpovídali na základě každodenní praxe, předpokládáme tedy, že se překážkami, chybami a možnými problémy zabývají více, pokud cítí potřebu, že je to přínosné, např. když si sami potřebují ujasnit situaci u obtížnější úlohy.

Tab. 9: Nesprávné strategie řešení

\begin{tabular}{|c|c|}
\hline První fáze & Druhá fáze \\
\hline $35 \%$ & $4 \%$ \\
\hline $11 / 31$ & $1 / 26$ \\
\hline
\end{tabular}

Nesprávné strategie jsme v př́pravách odhalili pouze ve $4 \%$ případi̊ (odpovídá jedné přípravě). Přitom v dotazníku to bylo $35 \%$. Může to být dáno typem úlohy, nebo učitelé o nesprávných strategiích vědí, ale nevidí důvod je do př́ípravy zapisovat. Není samozřejmě možné vymyslet všechny nesprávné strategie, pouze ty nejpravděpodobnější. Jejich výskyt je ovlivněn např. úlohami, které žáci řešili dříve, tématem, kterým se aktuálně v matematice zabývají apod.

B) Srovnatelný výsledek (rozdíl do $5 \%$ )

Tab. 10: Srovnatelný výsledek

\begin{tabular}{|l|c|c|c|c|}
\hline & \multicolumn{2}{|c|}{ První fáze } & \multicolumn{2}{c|}{ Druhá fáze } \\
\hline Předchozí znalosti & $68 \%$ & $21 / 31$ & $65 \%$ & $17 / 26$ \\
\hline Správné strategie řešení & $61 \%$ & $19 / 31$ & $62 \%$ & $16 / 26$ \\
\hline
\end{tabular}


Tab. 11: Téma hodiny

\begin{tabular}{|c|c|}
\hline První fáze & Druhá fáze \\
\hline $94 \%$ & $85 \%$ \\
\hline $29 / 31$ & $22 / 26$ \\
\hline
\end{tabular}

Téma hodiny učitelé zapisují do třídní knihy, najdou je v učebnicích, žáci se učitelů často ptají na „nadpis hodiny“. V dotazníku $93 \%$ odpovědělo, že téma hodiny uvádějí vždy nebo téměř vždy. Předpokládali jsme tedy, že téma hodiny v přípravě uvede většina učitelů a studentů, což se potvrdilo. Pouze 4 učitelé a studenti téma neuvedli. Vysvětlujeme si to tím, že neměli potřebu úlohu zařazovat do nějaké konkrétní učební látky. Jednalo se o úlohu nestandardní.

Tab. 12: Pomůcky

\begin{tabular}{|c|c|}
\hline První fáze & Druhá fáze \\
\hline ž: $74 \%$, u: $68 \%$ & $42 \%$ \\
\hline ž: $23 / 31$, u: $21 / 31$ & $11 / 26$ \\
\hline
\end{tabular}

V dotazníku byla tato otázka rozdělena na dvě: pomůcky, které budou potřebovat žáci (v tabulce označeno ,ž “'), do př́ipravy zahrnuje $74 \%$ respondentů, a pomůcky pro učitele (v tabulce „u“) zmiňuje $68 \%$ respondentů. V našich př́ípravách jsme poznámku týkající se pomůcek nalezli ve $42 \%$ př́padů. Zřejmě se jedná o složku, kterou někteří učitelé a budoucí učitelé nepovažují za nutné zapisovat, protože $\mathrm{k}$ dané úloze na základě své přípravy žádné pomůcky nepotřebovali. V dotazníku si respondenti představovali různé úlohy, a u mnoha z nich jsou pomůcky nutné.

Tab. 13: Způsob hodnocení

\begin{tabular}{|c|c|}
\hline První fáze & Druhá fáze \\
\hline $3 \%$ & $12 \%$ \\
\hline $1 / 31$ & $3 / 26$ \\
\hline
\end{tabular}

Způsob hodnocení byl v přípravách navržen ve $12 \%$ případů. V dotazníku se objevil v jednom případě, a to jako složka přípravy, kterou analýza a priori neobsahovala, ale respondent ji považoval za důležitou.

\subsubsection{SROVNÁNí VÝSLEDKŮ SKUPINY EXPERTŮ A SKUPINY ZAČÁTEČNÍKŮ}

Skupinu začátečníků, tedy studentů učitelství, tvořilo 16 studentů učitelství matematiky. Úkol jim byl zadán jako seminární práce v rámci předmětu didaktika matematiky. Studenti měli za sebou většinou pouze několik odučených hodin v rámci oborové praxe. Skupinu expertů, tedy učitelů, tvořilo 10 učitelů s délkou praxe od 3 do 25 let.

Nyní se podíváme, jaké rozdíly se objevily v přípravách studentů učitelství matematiky a učitelů matematiky (obr. 4). Vzhledem k různému počtu respondentů ve srovnávaných skupinách uvádíme výsledky v procentech, v tabulkách 14 až 24 také absolutní počty. Srovnáváme přítomnost jednotlivých složek analýzy a priori v přípravách.

Složky jsme rozdělili do tř́i skupin podle míry odlišnosti. 


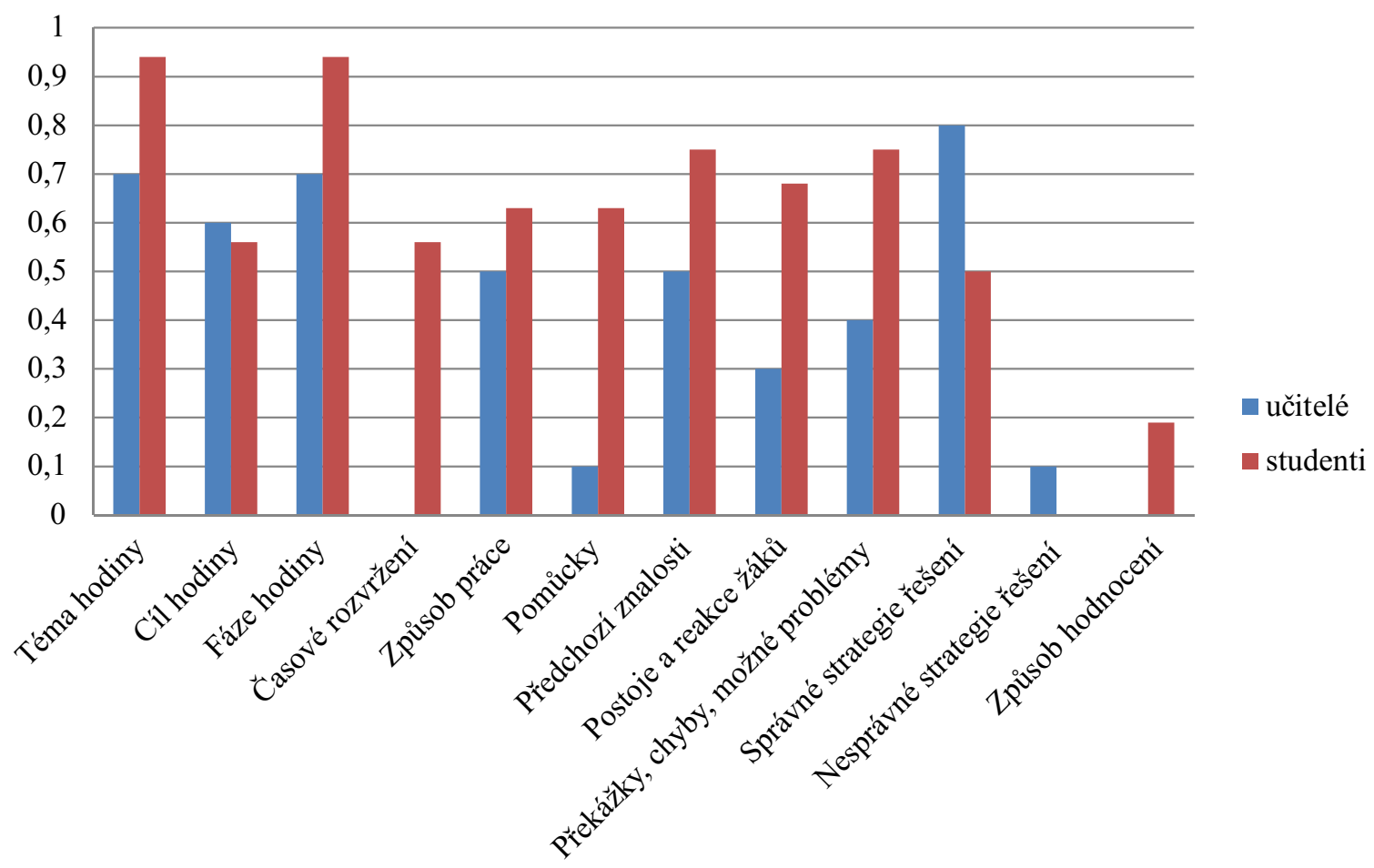

Obr. 4: Srovnání př́íprav učitelů a studenti̊

A) Složky s největšími rozdíly (20\% a více)

Tab. 14: Téma hodiny

\begin{tabular}{|c|c|}
\hline Studenti & Učitelé \\
\hline $94 \%$ & $70 \%$ \\
\hline $15 / 16$ & $7 / 10$ \\
\hline
\end{tabular}

Téměř všichni studenti a většina učitelů zapsali do svých příprav téma hodiny. Překvapilo nás, že téma hodiny nezapsalo více učitelů. Je možné, že by někteří učitelé úlohu zařadili jako zpestření výuky a nepovažovali za důležité ji někam zařazovat. Pro studenty bylo zařazení do tématu zjevně důležitější, předpokládáme, že jim umožňuje např. snadnější orientaci v učivu, na které bude úloha navazovat.

Tab. 15: Fáze hodiny

\begin{tabular}{|c|c|}
\hline Studenti & Učitelé \\
\hline $94 \%$ & $70 \%$ \\
\hline $15 / 16$ & $7 / 10$ \\
\hline
\end{tabular}

Téměř všichni studenti a většina učitelů hodinu rozdělili na fáze. Může to být proto, že příprava je potom přehlednější, snadněji se upravuje během hodiny. Rozfázování provedlo také více studentů než učitelů. Někteří učitelé zř̌ejmě hodinu člení až v průběhu výuky.

Tab. 16: Časové rozvržení

\begin{tabular}{|c|c|}
\hline Studenti & Učitelé \\
\hline $56 \%$ & $0 \%$ \\
\hline $9 / 16$ & 0 \\
\hline
\end{tabular}


Více než polovina studentů provedla časové rozvržení jednotlivých aktivit. U učitelů se časové rozvržení neobjevilo ani v jednom př́ípadě. Vysvětlujeme si to tím, že učitelé díky zkušenostem odhadnou lépe čas, který danou aktivitou stráví, a necítí potřebu jej poznamenávat. $\mathrm{V}$ době, kdy studenti př́pravu vypracovávali, měli za sebou jednu odbornou praxi; při př́ipravě na praxi byli explicitně upozorňování na nutnost podrobného časového plánu pro vyučovanou hodinu.

Tab. 17: Pomůcky

\begin{tabular}{|c|c|}
\hline Studenti & Učitelé \\
\hline $63 \%$ & $10 \%$ \\
\hline $10 / 16$ & $1 / 10$ \\
\hline
\end{tabular}

Jak vidíme z tabulky, mnohem více studentů než učitelů si do přípravy poznamenalo pomůcky, které budou potřebovat. Učitelé vědí, jaké pomůcky standardně u sebe mají jak oni, tak žáci, proto je zřejmě tak často nezapisují. Studenti jsou v kurzu didaktiky matematiky vedeni k zapisování pomůcek do příprav, které odevzdávají jako seminární práce.

\section{Tab. 18: Předchozí znalosti}

\begin{tabular}{|c|c|}
\hline Studenti & Učitelé \\
\hline $75 \%$ & $50 \%$ \\
\hline $12 / 16$ & $5 / 10$ \\
\hline
\end{tabular}

Tři čtvrtiny studentů oproti polovině učitelů do přípravy zařadily předchozí znalosti, které budou žáci pro danou aktivitu potřebovat. Domníváme se, že zmínka o předchozích znalostech vychází z nutnosti zařadit úlohu do konkrétního ročníku, tj. jako učitel musím vědět, co žáci umí, aby mohli úlohu řešit. Překvapilo nás, že se touto problematikou zabývalo tolik studentů. Domnívali jsme se, že je to pro ně nesnadné - právě kvůli chybějícím zkušenostem.

Tab. 19: Reakce a postoje žáků

\begin{tabular}{|c|c|}
\hline Studenti & Učitelé \\
\hline $69 \%$ & $30 \%$ \\
\hline $11 / 16$ & $3 / 10$ \\
\hline
\end{tabular}

Reakce a postoje žáků zmínilo ve srovnání s učiteli dvakrát tolik studentů. Tento výsledek byl pro nás překvapivý, nepředpokládali jsme, že se studenti budou v takové míře zabývat reakcemi a postoji žáků k navrhovaným aktivitám, protože jim chybí zkušenost. Je možné, že se dokážou dobře vcítit do myšlení žáků, protože k nim mají věkově relativně blízko. Zároveň jsou k tomu vedeni v kurzu didaktiky matematiky.

Tab. 20: Překážky, chyby a možné problémy

\begin{tabular}{|c|c|}
\hline Studenti & Učitelé \\
\hline $75 \%$ & $40 \%$ \\
\hline $12 / 16$ & $4 / 10$ \\
\hline
\end{tabular}

Velký rozdíl ve prospěch studentů se projevil také v popisu překážek, chyb a problémů, které by mohly nastat. Zde jsme neočekávali, že se bude touto problematikou 
zabývat tolik studentů. Domnívali jsme se, že, když ještě nemají s výukou velké zkušenosti, je pro ně obtížné odhadnout, jakých chyb se mohou žáci dopustit. Výskyt překážek, chyb a možných problémů v př́pravách studentů si vysvětlujeme tím, že studenti ještě mají schopnost vcítit se do myšlení žáků a vzpomenout na svá školní léta. Zároveň je v kurzu didaktiky matematiky kladen na problematiku chyb velký důraz. Při probírání jednotlivých témat školské matematiky se mluví vždy o problémech, které se mohou objevit, o tom, co je pro žáky náročné a jakých chyb se často dopouštějí.

Tab. 21: Správné strategie řešení

\begin{tabular}{|c|c|}
\hline Studenti & Učitelé \\
\hline $50 \%$ & $80 \%$ \\
\hline $8 / 16$ & $8 / 10$ \\
\hline
\end{tabular}

Tentokrát se rozdíl projevil ve prospěch učitelů. Zajímavé bylo, že někteří studenti v přípravách vůbec neuvedli správné řešení úlohy. Vedoucí kurzu didaktiky matematiky se domnívá, že to může být způsobeno tím, že příprava, kterou jsme od studentů vyžadovali, byla hypotetická. Studenti ji ve skutečnosti neodučili. Kdyby věděli, že ji ve výuce použijí, řešení by spíše uvedli.

\section{B) Vyrovnané složky (rozdíl $10 \%$ a méně)}

Složky, v nichž se rozdíl mezi učiteli a studenty neprojevil, jsou okomentovány výše ve srovnání první a druhé fáze výzkumu. V tab. 22 jsou pro zajímavost uvedeny číselné hodnoty.

Tab. 22: Vyrovnané složky

\begin{tabular}{|c|c|c|}
\hline Složka přípravy & Studenti & Učitelé \\
\hline \multirow{2}{*}{ Cíl hodiny } & $56 \%$ & $60 \%$ \\
\cline { 2 - 3 } & $9 / 16$ & $6 / 10$ \\
\hline \multirow{2}{*}{ Nesprávné strategie } & $0 \%$ & $10 \%$ \\
\cline { 2 - 3 } & 0 & $1 / 10$ \\
\hline
\end{tabular}

C) Ostatní složky

Tab. 23: Způsob práce

\begin{tabular}{|c|c|}
\hline Studenti & Učitelé \\
\hline $63 \%$ & $50 \%$ \\
\hline $10 / 16$ & $5 / 10$ \\
\hline
\end{tabular}

Způsob práce do přípravy poznamenalo $63 \%$ studentů a $50 \%$ učitelů. Z výsledku vyplývá, že se studenti zabývají zpo̊sobem práce o něco více než učitelé. To opět vychází z toho, že učitelé mají mnohem větší zkušenosti než studenti.

Tab. 24: Způsob hodnocení

\begin{tabular}{|c|c|}
\hline Studenti & Učitelé \\
\hline $19 \%$ & $0 \%$ \\
\hline $3 / 16$ & 0 \\
\hline
\end{tabular}


Způsob hodnocení popsalo $19 \%$ studentů a žádný učitel. Domníváme se, že učitelé hodnocení nezapisují, protože mají stanovený systém, který uplatňují celý školní rok. Studenti si ho teprve tvoří, a proto se téměř u pětiny z nich objevil návrh, jak jednotlivé aktivity $\mathrm{v}$ hodině hodnotit. $\mathrm{V}$ jednom př́padě student učitelství $(\mathrm{S})$ navrhuje i sebehodnocení žáků:

S: „Na konci hodiny žáci řeknou, co se naučili.“

\subsubsection{ROZDĚLENÍ PŘÍPRAV}

V průběhu analýzy příprav od učitelů i studentů jsme na základě (ne)přítomnosti určitých složek analýzy a priori vytvořili dvě skupiny, do kterých by se přípravy daly rozdělit: př́ipravy zaměrené na učitele a př́pravy zaměrené na učitele a žáky zároveñ.

a) Přípravy zaměřené na učitele: Tyto přípravy obsahovaly vždy téma hodiny, cíl hodiny, fáze hodiny, většinou pomůcky, předchozí znalosti a správné strategie řešení. Nejednalo se často o strategie, které by mohli použít žáci, ale spíše o postup, jakým by řešil úlohu sám učitel. Jakoby žáci neexistovali, učitel vybere aktivity, vyřeší je a jde do třídy. Tento typ příprav se objevil celkem v 16 prŕpadech, u 7 učitelů (z 10), u 9 studentů (ze 16).

b) Přípravy zaměřené na učitele a žáky zároveñ: Jsou to přípravy, které se zabývaly navíc také způsobem práce žáků, jejich postoji a reakcemi $\mathrm{k}$ dané aktivitě, překážkami, chybami a možnými problémy a správnými strategiemi řešení žáků. Tento typ příprav se objevil celkem v 10 případech, u 3 (z 10) učitelů, u 7 (ze 16) studentů.

\subsection{PřÍPRAVY STUDENTŮ A UČITELŮ A NAŠE ANALÝZA a priori}

V této části porovnáme naši analýzu a priori Diofantovy úlohy s přípravami získanými od učitelů a studentů z obsahového hlediska. V závěru každého odstavce se vždy pokusíme odhadnout, jaký vliv na skutečný průběh hodiny by mohlo mít vynechání dané položky v př́pravě učitelů. Budeme postupně sledovat a analyzovat následující složky analýzy a priori: téma, cíl úlohy, čas, který bude úloze věnován, způsob práce, pomůcky, proměnné, předchozí znalosti, postoje a reakce žáků, správné strategie řešení, nesprávné strategie řešení a způsob hodnocení.

Složky charakter zadání a postoje a reakce učitelů srovnávat nebudeme. V př́ipravě na hodinu je nelze identifikovat, jsou spíše její implicitní součástí. V naší analýze a priori byly ale př́nosné právě pro př́pravu výzkumu.

\subsubsection{SROVNÁNí PŘíPRAV S NAŠí ANALÝZOU a priori}

- Téma hodiny: V naší analýze a priori jsme navrhovali zařazení úlohy do 7. ročníku základní školy v rámci tematického celku Lineární rovnice nebo na gymnáziu do 1. ročníku, když se probírají různé typy rovnic.

Studenti a učitelé tuto možnost také uvedli (ve třech př́ipadech). Ale objevila se i další témata. Nejčastěji (v sedmi případech) studenti a učitelé navrhovali téma Slovní úlohy řešitelné soustavou dvou rovnic o dvou neznámých (9. ročník). Ve dvou případech byla úloha zařazena do tématu Lineární funkce a jejich grafy (8. ročník). Dvakrát se objevilo téma Posloupnosti (4. ročník). V jednom případě byla úloha 
zařazena do celohodinového tématu týkajícího se diofantovských rovnic (2. ročník střední školy). Dále se jednou vyskytla témata Dělení celku na nestejné části (6. ročník) a Č́slo a proměnná (5. ročník).

Nyní se zamyslíme nad tím, jaký vliv na výuku by mohlo mít vynechání položky „téma“ v přípravě učitele. Pokud učitel nezařadí úlohu do konkrétního tématu, může ji použít kdykoliv během roku. Musí si jen ujasnit, jaké znalosti žáci k řešení úlohy potřebují. Žákům tak naznačuje, že úlohu mohou řešit různým způsobem. Tím, že žáci nevědí, „kam úloha patří“, nemuseli by být limitováni volbou řešitelské strategie.

- Cíl úlohy: V naší analýze a priori jsme zformulovali cíl úlohy z hlediska matematického a didaktického (viz oddíl 4.2).

V přípravách jsme identifikovali většinou obecné cíle, týkající se celého tematického celku, ne konkrétní úlohy. Rozdělili jsme je do dvou skupin, cíle formulované z pozice učitele a cíle formulované z pozice žáka ( $\mathrm{v}$ našem případě se jedná vlastně o výstupy, tak jak jsou popsány v rámcovém vzdělávacím programu, případně školním vzdělávacím programu).

- Cíle formulované z pozice učitele: Např.: „Uzavření tématu lineárních rovnic, uvedení přechodu k rekurentnímu zápisu posloupnosti, procvičování násobilky, procvičování počítání zpaměti.“

- Cíle formulované z pozice žáka: Např.: „Žák dokáže sestavit soustavu dvou lineárních rovnic o dvou neznámých a dopočítá její kořeny; užívá sčítací i dosazovací metodu řešení, dokáže řešení dané soustavy znázornit graficky, žáci použijí algoritmus řešení diofantovské rovnice, žáci si doplňují a upevňují učivo o lineárních funkcích, že písmenko může nabývat právě jednu hodnotu, aby byli schopni vyřešit jednoduché lineární rovnice."

Pokud se učitel nezamyslí nad cílem úlohy, může se stát, že si zcela neuvědomí potenciál úlohy. $\mathrm{V}$ našem případě se jedná o množství řešitelských strategií. $\mathrm{S}$ žáky pak bude pravděpodobně úlohu řešit pouze jedním zpơsobem (pokud sami žáci nepřijdou s jiným). Učitel by měl být schopen smysluplně žákům odpovědět na častou otázku „Proč se to učíme? K čemu nám to bude?"

Konkrétní cíl úlohy tak, jak jsme jej formulovali v naší analýze a priori, by měl být žák schopen zformulovat sám. Je vlastně podmínkou pro řešení úlohy. Pokud se tak nestane, pravděpodobně nebude schopen úlohu správně vyřešit. Pak je na učiteli, aby např. v rámci společné kontroly cíl úlohy objasnil.

- Čas: V naší analýze a priori jsme odhadovali, že práci s úlohou může učitel věnovat až polovinu vyučovací hodiny. Učitelé a studenti úlohu využili dvojím způsobem. Jako součást opakování a rozšíření probíraného tématu (např. soustavy dvou lineárních rovnic o dvou neznámých) - v tom případě úloze věnovali většinu hodiny. $\mathrm{V}$ druhém případě byla úloha součástí podobných úloh, které učitelé a studenti vymysleli a jejichž řešením se zabývali celou hodinu, v jednom případě i dvě vyučovací hodiny (např. posloupnosti, číslo a proměnná).

V případě, že učitel v rámci prŕípravy neprovede časový odhad, může dojít k překvapivé situaci pro něj i pro žáky. Úloha bude vyřešena během chvilky a učitel bude rychle vymýšlet další náplň hodiny, nebo naopak úlohu nestihne vyřešit a bude muset pokračovat př́ště, nebo ji zadat jako domácí úkol. 
- Způsob práce: V naší analýze a priori jsme zvolili práci ve dvojicích nebo ve skupinách, úloha je podle našeho názoru neobvyklá, a někteří žáci by mohli mít problém už jen s pochopením zadání. Tento způsob práce navrhovali často i učitelé. Studenti většinou dali přednost společné práci (diskuze učitele s žáky, společné řešení na tabuli) a samostatné práci s následnou diskuzí.

- Pomůcky: V naší analýze jsme navrhli tyto pomůcky: sešit, tužka, pro větší čísla kalkulačka, program Excel. Kromě těchto pomůcek studenti a učitelé ještě zapsali: projektor a plátno (grafy), kuličky, pracovní listy, čtverečkový papír, krokovací pás, program Funkce, internetové zdroje, učebnice.

$\mathrm{V}$ př́padě, že učitel předem nepromyslí, jaké pomůcky bude $\mathrm{s}$ žáky $\mathrm{k}$ řešení úlohy potřebovat, se může stát, že žáci nebudou moci realizovat některé řešitelské strategie. Žáci tak mohou být ochuzeni o některé postupy řešení a úloha zůstane nevyužita.

- Proměnné: V naší analýze a priori jsme popsali proměnné, které zadání úlohy obsahuje. Zajímalo nás, jakým způsobem a zda učitelé původní zadání úlohy modifikovali.

Ukázalo se, že většina učitelů a studentů úlohu upravila v závislosti na tematickém celku, do kterého úlohu zařadili. Celkem 4 učitelé a 4 studenti nechali úlohu v nezměněné podobě. Další 2 studenti nechali úlohu v nezměněné podobě s tím, že žákům poradí, at̉ si dané číslo zadají sami. Nejvíce studentů a učitelů měnilo kognitivní proměnnou „dané číslo“ a zadalo toto číslo konkrétně. Tři studenti a 4 učitelé zadali konkrétní dané číslo bez dalších úprav zadání. Dva studenti zadali konkrétní dané číslo a vytvořili slovní úlohu (měnili tedy i formulační proměnné). Čtyři studenti a 2 učitelé navrhli sérii gradovaných úloh, ve kterých postupně přidávali a měnili tyto kognitivní proměnné: dané číslo, dvě části, trojnásobek, zvětšený, o čtyři. Jeden student navrhl, aby podle zadání (nezměněného) vytvořili žáci posloupnost a zapsali ji pomocí vzorce pro $n$-tý člen.

„Alena a Adam mají dohromady 135 let. Přitom Adam je o 3 roky starší. Alena má ... let. Adam má ... let."

Pokud učitel není schopen nebo ochoten úlohy upravovat s ohledem na věk a schopnosti svých žáků, může se stát, že s žáky některé úlohy (jako např. Diofantovu úlohu) nebude zkoušet řešit.

- Předchozí znalosti: V naší analýze a priori jsme stanovili následující znalosti nezbytné pro řešení úlohy: číselné obory $\mathrm{N}$ a Z, dělitelnost, pojmy násobek, menší a větší část.

Učitelé a studenti ve svých př́pravách opět vycházeli z tématu, do kterého úlohu zasadili: zadání posloupnosti vzorcem pro $n$-tý člen, lineární rovnice o jedné neznámé, soustava dvou rovnic o dvou neznámých, práce s proměnnou.

Pokud učitel nepromyslí, jaké znalosti budou žáci k řešení úlohy potřebovat, může se stát, že si s úlohou nebudou vědět rady, protože ještě nezískali potřebné znalosti.

- Postoje a reakce žáků: V naší analýze a priori jsme se pokusili odhadnout celkový postoj žáků k úloze. Předpokládali jsme, že se objeví na začátku žáci, kteří hned nějaké řešení uhodnou, a žáci, kteří si nebudou vědět rady. Domnívali jsme se, že je může překvapit obtížná srozumitelnost zadání a fakt, že cesta ke správnému řešení vyžaduje více kroků v uvažování.

Podobná reakce se objevila i v jedné př́pravě studenta: „Předpokládám, že žáci budou tvrdit, že zapsanou rovnici neumí vyř̌šit, nebot se jim v rovnici objevují 
dvě neznámé. Spíše si myslím, že nikdo nepřijde na to, že za jednu neznámou může dosadit nějaké číslo a druhou pak vypočítat ze zapsané rovnosti."

Učitelé a studenti jinak uváděli častěji reakce na konkrétní situaci, např. jeden studen napsal: „Stále si myslím, že někdo na to půjde odhadem, protože se jedná o malé číslo, nicméně si myslím, že někoho napadne, že číslo 12 musí rozdělit na 4 díly." 18

Postoje a reakce žáků lze obtížně odhadnout, výhodou je pro učitele zkušenost a schopnost vcítit se do myšlení žáků.

- Správné strategie řešení: V naší analýze a priori jsme navrhli celkem pět správných řešitelských strategií, se kterými by mohli žáci přijít: diofantovská rovnice, systematické experimentování, metoda pokus-omyl, graf a obrázek. Studenti a učitelé navrhovali kromě těchto strategií také soustavu dvou rovnic o dvou neznámých, lineární rovnici, modelování (pomocí kuliček).

Zajímavé je, že řešení pomocí soustavy rovnic, lineární rovnicí a diofantovskou rovnicí navrhovali pouze studenti. Vzhledem $\mathrm{k}$ věku žáků se jedná o poměrně náročné strategie. Učitelé navrhovali grafické řešení, řešení pomocí obrázku (ve třech př́ípadech úsečka, v jednom koláč) a systematické experimentování. Tedy strategie, které od žáků nevyžadují tak náročný matematický aparát, ale spíš tvořivost a úvahu.

Pokud učitel nepromyslí správné strategie řešení, může se stát, že žáci přijdou s překvapivým postupem řešení, který vede ke správnému výsledku, ale např. není správný, nebo využívá znalosti, které ještě ostatní žáci nemají. Pokud učitel v rámci přípravy způsoby řešení promyslí, bude schopen pohotově reagovat a takové situace budou pro něj snadnější.

- Nesprávné strategie řešení: Možnost volby nesprávné strategie řešení uvedl pouze jeden učitel (obr. 5). Příčinou je špatné porozumění zadání. Jedná se o nesprávnou strategii, kterou jsme popsali v naší analýze a priori.

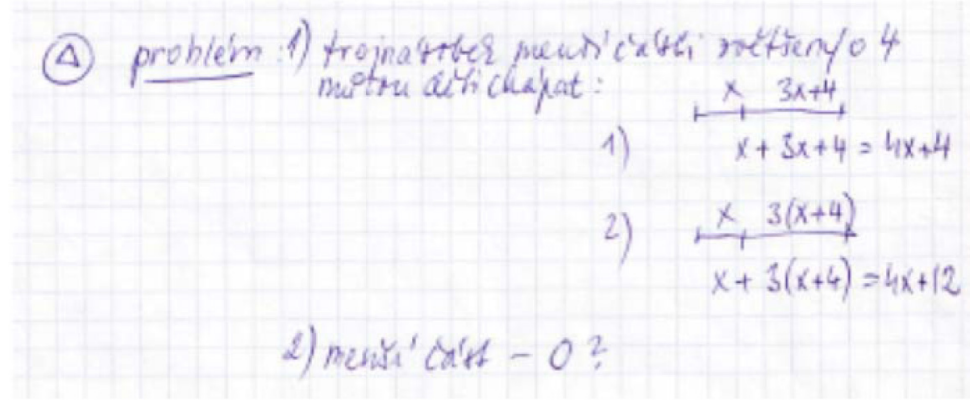

Obr. 5: Nesprávná strategie

Výskyt a povaha nesprávných strategií záleží například na zpo̊sobu řešení úlohy, na tématu, kterým se žáci právě zabývají, na zažitých stereotypech žáků při řešení úloh. Velkou roli hraje také zkušenost učitele.

- Způsob hodnocení: V naší analýze a priori vycházel způsob hodnocení ze způsobu práce. Navrhovali jsme práci ve skupinách. Členové skupiny, kteří úlohu správně vyřeší, získají jedničku. Ostatní skupiny navrhujeme ohodnotit pouze slovně.

Způsob hodnocení byl zmíněn ve dvou přípravách studentů. První z nich navrhoval samostatnou práci na tři malé jedničky, druhý (jedná se o studenta s praxí

\footnotetext{
${ }^{18}$ Tato strategie řešení je ale nesprávná.
} 
2 roky) vysvětlil svůj celkový systém hodnocení: „Během první hodiny hodnotím pouze slovně. Povzbuzuji studenty, aby se nebáli ptát a sdělili ostatním, co jim dělá problém, co je napadlo, čeho si všimli. Výsledky kontroluji průběžně, snažím se nevynechat nikoho ve svých kontrolních otázkách prověřujících pochopení tématu. Po celkovém probrání a procvičení látky píšeme větší opakovací test, ve kterém shrneme dané téma."

Pokud učitel nerozmyslí, jakým způsobem bude jednotlivé aktivity v hodině hodnotit, může se stát, že snadný i obtížný úkol ohodnotí stejným způsobem (např. známkou, která bude mít stejnou váhu v celkovém hodnocení).

\subsubsection{NOVÉ SLOŽKY V PǨÍPRAVÁCH STUDENTU゚ A UČITELŮ}

V přípravách studentů i učitelů se objevily složky, které jsme do naší analýzy zařazeny neměli. Bylo jich méně než v první fázi experimentu: motivační úloha na úvod, návodné otázky, klíčové kompetence a domácí úkol. Stejně jako v první fázi experimentu jsme tyto složky rozdělili do dvou skupin:

Konkretizace námi navržené př́pravy, jeji uvedeni do praxe, jako např.: motivační rozcvičky, úvodní problémová úloha (ve čtyřech přípravách), návodné otázky (ve dvou př́padech).

„Nové" složky př́pravy, které se v naši př́pravě neobjevily: klíčové kompetence (v jednom případě), domácí úkol (v šesti přípravách).

a) Domáci úkol:19 Návrh domácího úkolu se objevil na závěr v pěti přípravách studentů a v jedné přípravě učitele. Identifikovali jsme dva typy úkolio, u každého typu uvádíme typický př́klad:

- Vytvořte podobnou úlohu (bez bližší specifikace): „Vymyslete podobnou úlohu s rozdělením čísla na části, které mají nějaké vlastnosti.“

- Vyřešte slovní úlohu (řešitelnou lineární rovnicí, soustavou rovnic, experimentováním): „Podíl dvou čísel je 4, jejich součet je 75. Urči obě čísla.“

b) Návodné otázky: Ve dvou přípravách studentů a jednoho učitele se objevily návodné otázky, které by měly žákům pomoci s řešením úlohy: „Bude zde jen jedno řešení?" „Chybí mi některý údaj? Který?" „Co se stane, když si tento údaj vymyslím?"

c) Motivační úloha: $\mathrm{V}$ pěti přípravách učitelů byla $\mathrm{v}$ úvodu zapracována motivační úloha na úvod do problematiky (ukázka viz obr. 6).

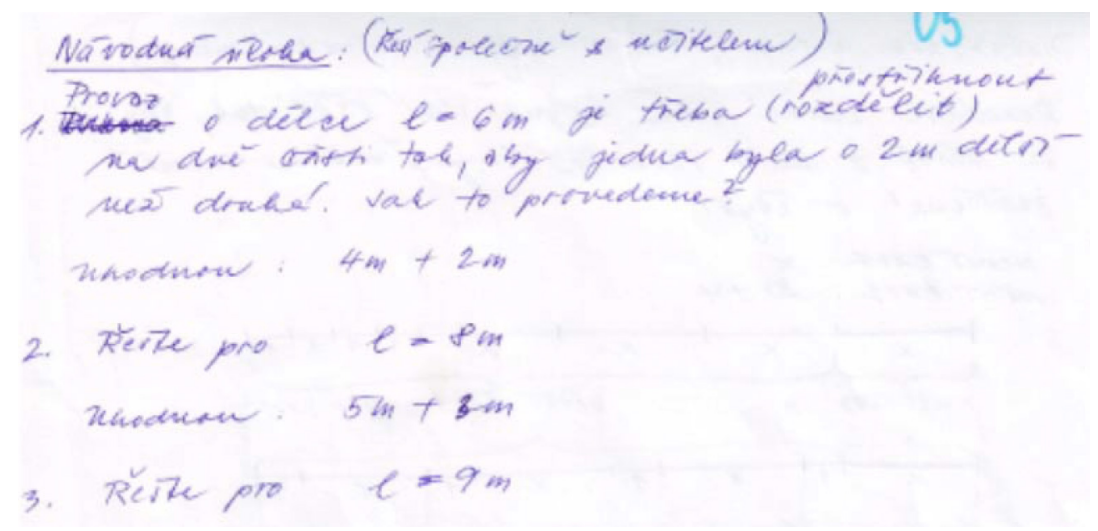

Obr. 6: Návodná úloha

\footnotetext{
${ }^{19}$ Domácí úkol a návodné otázky se v první fázi výzkumu nevyskytly.
} 


\section{ZÁVĚR}

První fáze experimentu potvrdila, že učitelé, a to nejen začínající, ale i zkušení, přikládají většinou podrobné přípravě výuky velký význam. V našem vzorku se ukázal rozdíl mezi učiteli na 1. a na 2. stupni školy hlavně v těchto položkách: pomůcky pro učitele a žáky, předchozí znalosti, postoje a reakce žáků, překážky, chyby a možné problémy, správné a nesprávné strategie řešení. Tento rozdíl je podle našich analýz způsoben hlavně rozdíly v obsahu a rozsahu probíraného učiva.

Předpokládali jsme, že skutečné přípravy nebudou obsahovat všechny položky, které učitelé a budoucí učitelé uváděli v dotazníku. Toto očekávání se potvrdilo pouze částečně. Ve srovnání s odpověd’mi v dotazníku se ve skutečných přípravách méně vyskytovaly složky cíl hodiny, fáze hodiny a časové rozvržení, způsob práce a nesprávné strategie řešení. Naopak složky postoje a reakce žáků, překážky, chyby a možné problémy se častěji objevily v př́ipravách než v dotazníku.

Předpokládali jsme, že př́pravy studentů budou bohatší po formální a organizační stránce, budou častěji obsahovat téma hodiny, fáze hodiny, časové rozvržení, způsob práce, pomůcky, způsob hodnocení. Očekávali jsme, že př́pravy učitelů budou více zaměřeny na žáka, budou častěji zmiňovat předchozí znalosti, reakce a postoje žáků, překážky, chyby a možné problémy, správné i nesprávné strategie řešení. Tato naše očekávání se nepotvrdila. Studenti do svých příprav skutečně častěji zařazovali téma hodiny, fáze a časové rozvržení, pomůcky, ale také se ve větší míře než učitelé zabývali předchozími znalostmi, reakcemi a postoji žáků a překážkami, chybami a možnými problémy. Jak již bylo uvedeno, mohlo to být zpơsobeno jejich zkušeností z pedagogických praxí a úkolů, které v rámci nich plnili. Učitelé své přípravy zpracovali více po formální a organizační stránce.

Předpokládali jsme, že bude možné na základě př́itomnosti/nepřítomnosti určitých složek analýzy a priori rozdělit přípravy učitelů a studentů do skupin. Vytvořili jsme dvě kategorie př́iprav: přípravy zaměřené na učitele a přípravy zaměřené na učitele a žáka zároveň.

Výzkum propojení analýz a priori a př́iprav učitelů není ve vědeckých publikacích zpracováván příliš často. Přitom je význam takových studií jak pro praxi, tak pro výzkum velký; analýza a priori umožňuje podrobněji zkoumat přípravy učitelů a poskytuje tak základ pro další práci s nimi - at výzkumnou (např. při provádění analýzy a posteriori) či praktickou (např. při plánování výuky). Domníváme se, že se nám podařilo získat vhled do této problematiky, i když si uvědomujeme, že vzorek učitelů a studentů je zatím příliš malý.

V předkládaném výzkumu jsme se zaměřili na porovnání analýzy a priori podle TDSM se skutečnými př́pravami učitelů na výukovou jednotku. Sledovali jsme zařazování/nezařazování jednotlivých prvků z analýzy a priori do př́prav a důsledky, které vynechání některé složky může mít na průběh př́islušné výukové jednotky. V úvahu jsme brali pouze tři skupiny respondentů, dál už jsme je nedělili podle dalších proměnných (např. podle délky praxe, pohlaví). Při větším vzorku respondentů by takové rozdělení jistě obohatilo získané výsledky o dalšś zjištění, která by měla velký význam jak pro učitelskou praxi, tak i pro přípravu budoucích učitelů.

Dotazníkové šetření v první fázi výzkumu by mohlo být doplněno rozhovory s vybranými respondenty, což by umožnilo doplnit další zajímavé podrobnosti hlavně v položkách, kde jsou velké rozdíly v odpovědích.

Naším hlavním cílem bylo sledovat odpovědi na výzkumné otázky v př́ipadě výuky matematiky. Další možné rozšiřrení výzkumu vidíme v hledání shod a rozdílů mezi učiteli matematiky a jiných předmětů a odhalování jejich příčin. Jiné možné 
pokračování výzkumu by mohlo být zaměřeno na hledání shody mezi přípravou učitele a skutečně odučenou hodinou.

\section{LITERATURA}

BROUSSEAU, G. Theory of didactical situations in mathematics. N. Balacheff, M. Cooper, R. Sutherland, V. Warfield, (Eds. \& Trans). Dordrecht : Kluwer, 1997.

BROUSSEAU, G. Théorie des situations didactiques. [Textes rassemblés et préparés par N. Balacheff, M. Cooper, R. Sutherland, V. Warfield]. Grenoble : La pensée sauvage, 1998.

BROUSSEAU, G. Úvod do Teorie didaktických situací v matematice. Praha : Univerzita Karlova, Pedagogická fakulta, 2012.

BROUSSEAU, G., SARRAZY, B. Glossaire de quelques concepts de la théorie des situations didactiques en mathématiques. Bordeaux : DAEST, Université Bordeaux 2, 2002.

CHARNAY, R. L'analyse a priori, un outil pour l'enseignant. In Grugnetti, Jaquet, Medici, Polo, Rinaldi (Eds.) Actes des journées d'étude sur le Rally mathématique transalpin, RMT: potentialités pour la classe et la formation, Vol. 3, s. 199-213. ARMT : Dip. di Mat. Università di Parma, Dip. Mat. Università di Cagliari, 2003.

DIVÍŠEK, J. Didaktika matematiky pro učitelství 1. stupně Zঙ̆. Praha : SPN, 1989.

FERMAT, P. Précis des Euvres mathématiques et de l'Arithmétique de Diophante, par É. Brassine. Toulouse : Imprimerie de Jean-Mathieu Douladoure, 1853. Reprint 2005 .

HARMER, J. The Practice of English Language Teaching. London and New York : Longman Handbooks for Language Teachers, 1992.

HAUSENBLAS, O. a kol. Klíčové kompetence na gymnáziu. Praha : Výzkumný ústav pedagogický, 2008.

HRABÁKOVÁ, H. Využití Teorie didaktických situací v prostředí české školy. [Diplomová práce]. Praha : Univerzita Karlova, Pedagogická fakulta, 2005.

MUTTON, T., HAGGER, H., BURN, K. Learning to plan, planning to learn: the developing expertise of beginning teachers. Teachers and Teaching, 2011, 17(4), p. 399-416.

NOVOTNÁ, J. Ukázky analýzy a priori pro slovní úlohy. P. Dvořák, J. Herman (Eds.). Sborník z J S̆DS Vrabcov, jaro 2003. Praha : Univerzita Karlova, Pedagogická fakulta, OR Didaktika matematiky, 2003a, s. 31-54.

NOVOTnÁ, J. Didaktické situace ve vyučování matematice. [Přednáška]. Vzdělávání učitelů. Seminář učitelů matematiky okresu Mladá Boleslav. Pořadatel SPI Mladá Boleslav, 2003b.

NOVÁKOVÁ, H. Analýza a priori jako součást přípravy učitele na výuku. [Dizertační práce]. Praha: Univerzita Karlova, Pedagogická fakulta, 2013.

OBST, O. Projektování výuky. In Z. Kalhous, O. Obst, a kol. (Eds.), Školni didaktika. Praha : Portál, 2002, s. 354-365. 
PANASUK, R. M., TODD, J. Effectiveness of Lesson Planning: Factor Analysis. Journal of Instructional Psychology, 2005, 32(3), p. 215-232.

RYS, S. Hospitace v pedagogické praxi. Praha : SPN, 1975.

SPAGNOLO, F., ČIŽMÁR, J. Komunikácia v matematike na strednej škole. Brno : Masarykova univerzita, Přírodovědecká fakulta, 2003.

TAYLOR, P. H. How teachers plan their courses. Slough, Berkshire : National Foundation for Educational Research in England and Wales, 1970.

TOCHON, F. V. A quoi pensent les enseignants quand ils planifient leurs cours? Revue Française de pédagogie, 1989, No. 86, p. 23-33.

WARD, R. A., ANHALT, C. O., VONSON, K. D. Mathematical Representations and Pedagogical Content Knowledge: An Investigation of Prospective Teachers' Development. In Focus on Learning Problems in Mathematics, 2003. 15 p. [ERIC Number: ED477697]

ZAHORIK, J. A. Teachers' planning models. Educational Leadership, 1975, 33(2), p. $134-139$.

\section{PODĚKOVÁNí}

Článek byl podpořen projektem GAČR P407/12/1939. Vychází z výsledků autorčiny doktorské disertační práce vytvořené pod vedením prof. RNDr. Jarmily Novotné, CSc. Autorka děkuje školitelce a doc. RNDr. Nadě Vondrové, Ph.D., za cenná doporučení při zpracování článku.

Mgr. Hana Nováková - E-mail: hanka.hrabakova@centrum.cz doktorandka, Univerzita Karlova v Praze, Pedagogická fakulta, Česká republika 